\title{
ČVRSTE POKROVITELJSKE IZJAVE - PRAVNA NARAV UGOVORA, PREDMET I POVREDA OBVEZE POKROVITELJA, STEČAJNI POSTUPAK I POSTUPAK IZVANREDNE UPRAVE
}

Doc. dr. sc. Tomislav Jakšić*

\author{
UDK 347.728 .5 \\ https://doi.org/10.30925/zpfsr.39.2.3 \\ Ur.: 2. listopada 2017. \\ Pr.: 6. ožujka 2018. \\ Izvorni znanstveni rad
}

\begin{abstract}
Sažetak
Čvrstom pokroviteljskom izjavom pokrovitelj preuzima obvezu pomaganja treće osobe radi njezina urednog ispunjenja osigurane obveze prema primatelju izjave. Takve su izjave redovito rezultat kompromisa kada se pokrovitelj $i$ primatelj izjave ne može dogovoriti o preuzimanju nekoga tradicionalnijeg sredstva osiguranja (npr. jamstva ili garancije). Izdavanjem pokroviteljske izjave nastaje ugovorni odnos koji se redovito kvalificira kao nepravi ugovor u korist trećega. Treća strana (dužnik), iako nije strana predmetnog ugovornog odnosa, redovito je povezana s pokroviteljem (npr. preko sudjelovanja u koncernu ili preko poduzetničkog ugovora) u čemu se nalazi i interes pokrovitelja za preuzimanjem takvog osiguranja. Rad obrađuje pravnu narav obveze pokrovitelja (posebice u usporedbi s jamstvom), pri čemu se dotiče i određenja naravi takvoga jednostranoobvezujućeg ugovora. Zatim se obrađuje sadržaj $i$ opseg pokroviteljeve obveze pomaganja, a potom i mogućnosti zamjene obveze pomaganja treće osobe ispunjenjem osigurane obveze izravno primatelju izjave. Obrađuju se i moguće povrede i nemogućnost ispunjenja obveze pomaganja te zaključno učinci stečajnog postupka i postupka izvanredne uprave na obvezu pokrovitelja. U tom pogledu analiziraju se i pravila o zajmu kojim se nadomješta temeljni kapital.
\end{abstract}

Ključne riječi: pokrovitelj, osiguranje, stečaj, izvanredna uprava, povezana društva.

\section{POJAM I PODJELA POKROVITELJSKIH IZJAVA}

Djelovanjem poslovne prakse u drugoj polovici 20. stoljeća nastaju pokroviteljske izjave (njem. Patronatserklärung i engl. Letter of Comfort). Kako je

* Dr. sc. Tomislav Jakšić, docent Pravnog fakulteta Sveučilišta u Zagrebu; tomislav.jaksic@ pravo.hr. 
takva izjava usmjerena na uredno ispunjenje osigurane obveze, proizlazi kako ona u pravnom prometu jača položaje ugovornih strana iz određenog osiguranog posla, primatelja izjave kao vjerovnika i treće osobe kao dužnika. ${ }^{1} \mathrm{U}$ ulozi pokrovitelja redovito nalazimo društvo majku ili članove društva treće osobe, a u ulozi primatelja izjave vjerovnika te treće osobe. Iz toga proizlazi kako je treća osoba redovito društvo kćer pokrovitelja ili društvo u kojem pokrovitelj (redovito većinski) član društva treće osobe. ${ }^{2} \mathrm{U}$ poredbenom pravu takve se izjave općenito dijele na čvrste i slabe pokroviteljske izjave. Izdavanje takvih izjava ranije je bilo motivirano ponajviše izbjegavanjem neke otegotne porezne, knjigovodstvene ili slične dužnosti koja se redovito vezala uz izdavanje tradicionalnih osiguranja (npr. uz izdavanje jamstva ili garancije). ${ }^{3} \mathrm{U}$ suvremenom pravnom prometu pokroviteljske izjave alternativa su tradicionalnim sredstvima osiguranja s time što, s jedne strane, omogućuju sklapanje glavnog ugovora u situacijama kada se interesne strane ne mogu dogovoriti oko sadržaja osiguranja za obvezu iz posla kojeg one žele sklopiti. S druge strane, takve izjave pokrovitelju, kao jednoj od interesnih strana, pružaju i veću fleksibilnost $i$ diskreciju vezano uz izbor načina i vrijeme ispunjenja osigurane obveze. ${ }^{4}$

Slabim pokroviteljskim izjavama smatraju se općenito izjave kojima pokrovitelj ne preuzima obvezu ispunjenja osigurane obveze ili njezina materijalnog pomaganja radi urednog ispunjenja osigurane obveze. ${ }^{5}$ Danom izjavom, međutim, pokrovitelj navodi kako će nešto učiniti ili kako će se suzdržati od nekakvog činjenja radi stvaranja osjećaja sigurnosti kod primatelja izjave i razvijanja povjerenja između ugovornih strana. ${ }^{6}$ Takve izjave stoga redovito ne dovode do nastanka utužive obveze što ne

1 U tom smjeru sa stajališta njemačke pravne književnosti vidi Horn, J., Patronatserklärungen in common law und im deutschen Recht, 1999., Frankfurt am Main, str. 16-18; Schnellecke, C., Wirksamkeit und Inhaltskontrolle harter Patronatserklärungen, 2005., Frankfurt am Main, str. 5-6. U tom smjeru sa stajališta austrijske pravne književnosti vidi Bollenberger, R., Kellner, M., u: Böhler, E., Bollenberger, R., Kellner, M., Laimer, S., Oppitz, M., Schwartze, A., Österreichisches Bankvertragsrecht, Band VIII: Kreidtsicherheiten, Teil I, 2. Aufl., 2012., Mörlenbach, Rbr. 4/1.

2 U tom smjeru vidi Schnellecke, C., op. cit. u bilj. 1, str. 6-7.

3 Tako vidi Koch, J., Patronatserklärung, 2005., Tübingen, str. 32; Horn, J., op. cit. u bilj. 1., str. 169-170; Schnellecke, C., op. cit. u bilj. 1., str. 8-9; Bollenberger, R., Kellner, M., op. cit. u bilj. 1, Rbr. 4/8-4/11; Kisser, J., Best Practice - Patronatserklärung, 2013., Wien, Rbr. 2.3.

4 U tom smjeru vidi Horn, J., op. cit. u bilj. 1, str. 170; Schnellecke, C., op. cit. u bilj. 1, str. 30; Kisser, J., op. cit. u bilj. 3, Rbr. 2.2. Između ostalog se navodi kako takvom izjavom pokrovitelj izjavljuje poslovnu solidarnost $\mathrm{s}$ trećom osobom bez preuzimanja ispunjenja osigurane obveze primatelju takve izjave. Tako vidi Kisser, J., op. cit. u bilj. 3., Rbr. 1.2.

5 Tako vidi Bollenberger, R., Kellner, M., op. cit. u bilj. 1, Rbr. 4/85; Koch, J., op. cit. u bilj. 3., str. 24; Kisser, J., op. cit. u bilj. 3, Rbr. 1.3.

6 U slabe pokroviteljske izjave ubraja se, primjerice, izjava o ostvarivanju utjecaja u društvu kćeri na način koji će osigurati uredno ispunjenje ugovorne obveze, zatim izjava kako će se u slučaju bitne promjene članske strukture pravovremeno obavijestiti primatelja izjave kao i izjava kojom se njezin davatelj obvezuje održati prvotni članski udio u društvu. U takve izjave spadaju i obične obveze obavještavanja primatelja izjave o okolnostima koje postoje u trenutku izdavanja takve izjave (npr. informacije o članskom udjelu pokrovitelja u strukturi treće osobe, o razini utjecaja kojeg pokrovitelj ostvaruje ili može ostvarivati u trećoj osobi, o zauzetoj poslovnoj politici pokrovitelja prema predmetnom poslu primatelja izjave i treće osobe). Više o tome vidi Bollenberger, R., Kellner, M., op. cit. u bilj. 1, Rbr. 4/86-4/87, 4/90; Horn, J., op. 
znači kako kod takvih izjava ne može doći do (ograničene) odštetne odgovornosti davatelja izjave, primjerice, u slučaju nepotpunosti ili netočnosti sadržaja dane izjave ili u slučaju postojanja predugovorne odgovornosti za štetu. ${ }^{7}$

S druge strane, čvrstim pokroviteljskim izjavama pokrovitelj se obvezuje poduzeti mjere pomaganja radi pribavljanja likvidnosti trećoj osobi kako bi ona bila u stanju uredno ispuniti osiguranu obvezu vjerovniku i primatelju te izjave (njem. Ausstatungsverpflichtung). ${ }^{8}$ Radi se o neformalnom i jednostranoobveznom sui generis ugovoru, u čijem je središtu obećanje pokrovitelja o materijalnom pomaganju treće osobe u cilju njezina urednog ispunjenja osigurane obveze primatelju izjave. ${ }^{9}$ Izdavanjem izjave nastaje utuživa obveza usmjerena na pribavljanje likvidnosti trećoj osobi. ${ }^{10}$ Pokroviteljska izjava, primjerice, glasi: izjavljujemo kako ćemo našem društvu kćeri svakodobno učiniti dostupna sredstva koja će joj omogućiti uredno ispunjenje svih obveza prema Vama ili izjavljujemo kako ćemo voditi brigu o tome da naše društvo za vrijeme trajanja osiguranog posla bude svakodobno financijski sposobno na uredno ispunjenje svih preuzetih obveza iz tog posla. ${ }^{11}$

U nastavku rada obrađuje se pravna narav ugovora i predmeta obveze pokrovitelja, sadržaj predmeta obveze pokrovitelja, a potom i opseg takve obveze pomaganja. Zatim se obrađuju mogućnosti pokrovitelja na ispunjenje osigurane obveze izravno primatelju izjave, a potom i slučajevi i moguće posljedice povrede i nemogućnosti ispunjenja takve obveze pomaganja. Zaključno se sagledavaju učinci stečajnog postupka, postupka izvanredne uprave te djelovanje pravila o zajmu kojim se nadomješta temeljni kapital na obvezu pokrovitelja.

cit. u bilj. 1., str. 107, 113, 116-117, 125, 139, 147; Schnellecke, C., op. cit. u bilj. 1., str. 7, 11-12; Tödter, C., Bürgschaft und Patronatserklärung, 2013., Hamburg, str. 32-38. Za stvaranje osjećaja sigurnosti i povjerenja vidi Schnellecke, C., op. cit. u bilj. 1., str. 11.

7 U tom smjeru vidi Schnellecke, C., op. cit. u bilj. 1., str. 11. Takva će slaba pokroviteljska izjava biti, primjerice, izjava o primanju na znanje nastanka određene okolnosti (npr. o tome kako je sklopljen određeni ugovor) i izjava kojim se izražava povjerenje u upravljačke sposobnosti uprave društva. Više o tome vidi Bollenberger, R., Kellner, M., op. cit. u bilj. 1., Rbr. 4/88, 4/92-4/93, 4/95.

8 Tako vidi Bollenberger, R., Kellner, M., op. cit. u bilj. 1., Rbr. 4/4, 4/20. U tom smjeru vidi Schnellecke, C., op. cit. u bilj. 1., str. 8, 19, 21-22.

9 Tako vidi Bollenberger, R., Kellner, M., op. cit. u bilj. 1., Rbr. 4/22, Koch, J., op. cit. u bilj. 3., str. 125; Schnellecke, C., op. cit. u bilj. 1., str. 23; La Corte, N., Die harte Patronatserklärung, Zugleich ein Plädoyer für eine geänderte Anlassrechtsprechung, 2006., Berlin, str. 299, 319; Tödter, C., op. cit. u bilj. 6., str. 24. Za suprotno stajalište austrijske pravne književnosti prema kojem se radi o formalnom ugovoru vidi Bollenberger, R., Kellner, M., op. cit. u bilj. 1., Rbr. $4 / 24$.

10 Tako vidi Schnellecke, C., op. cit. u bilj. 1., str. 19-20.

11 U tom smjeru vidi Koch, J., op. cit. u bilj. 3., str. 77; Horn, J., op. cit. u bilj. 1., str. 169; Schnellecke, C., op. cit. u bilj. 1, str. 19; La Corte, N., op. cit. u bilj. 9., str. 47; Bollenberger, R., Kellner, M., op. cit. u bilj. 1, Rbr. 4/20; Kisser, J., op. cit. u bilj. 3., Rbr. 3.2. 


\section{PRAVNA NARAV UGOVORA I PREDMETA OBVEZE POKROVITELJA}

Čvrstom pokroviteljskom izjavom preuzima se redovito uopćena obveza materijalnog pomaganja treće osobe (redovito kao korisnika kredita) radi njezina urednog ispunjenja vlastite obveze (redovito s naslova ugovora o kreditu) prema primatelju takve izjave (redovito banci kao davatelju kredita). ${ }^{12}$ Iz iznesenog je ponajprije vidljivo kako je takva obveza usmjerena na postizanje određenog rezultata kod treće osobe, tj. urednog ispunjenja osigurane obveze primatelju izjave. ${ }^{13} \mathrm{U}$ suprotnom, primjerice, pokroviteljevo pomaganje treće osobe (npr. uplatom nekoga novčanog iznosa na račun treće osobe) ima učinak ispunjenja obveze prema primatelju izjave neovisno o tomu ima li on od toga koristi (npr. je li treća osoba potom bila sposobna platiti dospjelu ratu kredita jer dobivena sredstva nisu iskorištena radi ispunjenja osigurane obveze) što obezvrjeđuje osiguravajuća funkcija takvih izjava. S druge strane, vezanost obveze i željenog rezultata znači i kako uredno ispunjenje osigurane obveze treće osobe, bez ikakve aktivnosti pokrovitelja usmjerene na takvo uredno ispunjenje, dovodi i do prestanaka pokroviteljeve obveze prema primatelju izjave. ${ }^{14}$ Iz toga proizlazi kako do prestanka obveze pomaganja može doći i bez ikakvog doprinosa pokrovitelja ispunjenju osigurane obveze treće osobe. Kako ispunjenje obveze pomaganja ovisi o postizanju određenog rezultata, pokrovitelj i dalje odgovara primatelju izjave ako treća osoba, unatoč primljenoj pomoći, nije u stanju uredno ispuniti osiguranu obvezu. Takva je odgovornost, međutim, ograničena samo na njezinu (materijalnu) sposobnost ispunjenja osigurane obveze (njem. Leistungsfähigkeit). To znači kako pokrovitelj ne odgovara i za postojanje volje treće osobe (emocionalnu spremnost) za ispunjenje osigurane obveze (njem. Leistungswilligkeit). ${ }^{15}$

Pored toga, obveza pomaganja jednostrana je obveza pokrovitelja (promitenta) prema primatelju izjave (stipulantu) koja se ispunjava trećoj osobi (korisniku). Radi se o nepravom ugovoru u korist trećega s pravnom osnovom u odredbi članka 164. stavka 1. Zakona o obveznim odnosima (dalje: ZOO). ${ }^{16}$ Prema toj odredbi ispunjenje obveze valjano je i kada je učinjeno trećoj osobi, ako je ono učinjeno temeljem ugovora vjerovnika i dužnika. Kod takvog ugovora treća osoba nema vlastito i neposredno pravo tražiti ispunjenje takve obveze od pokrovitelja, već može samo prihvatiti ili

12 U tom smjeru vidi Horn, J., op. cit. u bilj. 1., str. 171.

13 Tako vidi Koch, J., op. cit. u bilj. 3., str. 79, 91; Horn, J., op. cit. u bilj. 1., str. 179-180; Bollenberger, R., Kellner, M., op. cit. u bilj. 1., Rbr. 4/37; Tödter, C., op. cit. u bilj. 6., str. 39.

14 Tako vidi Koch, J., op. cit. u bilj. 3., str. 92. Iznesen je i izraz akcesornosti pokroviteljeve obveze prema osiguranoj obvezi. Više o tom svojstvu obveze s naslova pokroviteljske izjave vidi dalje u tekstu ovog poglavlja.

15 To znači kako odgovornost pokrovitelja ne obuhvaća i situacije kada treća osoba raspolaže potrebnim sredstvima za uredno ispunjenje osigurane obveze, ali to jednostavno ne čini. Tako vidi La Corte, N., op. cit. u bilj. 9., str. 100; Schnellecke, C., op. cit. u bilj. 1., str. 33; Bollenberger, R., Kellner, M., op. cit. u bilj. 1., Rbr. 4/38. U tom smjeru vidi Horn, J., op. cit. u bilj. 1., str. 197. Više o odgovornosti pokrovitelja za neispunjenje obveze vidi „5. Povreda i nemogućnost ispunjenja obveze pokrovitelja“.

16 Zakon o obveznim odnosima (NN, br. 35/05, 41/08, 125/11 i 78/15). 
odbiti ponuđeno ispunjenje (pomoć) kao ugovoreni primatelj ispunjenja. ${ }^{17}$ Zahtjev za ispunjenjem stoga može uputiti samo primatelj izjave, ali u korist ugovorenog primatelja ispunjenja ili treće osobe. U suprotnom bi se mogla ugroziti osiguravajuća funkcija pokroviteljske izjave. ${ }^{18}$ To ne znači kako se takvo osiguranje ne bi moglo preuzeti kao pravi ugovor u korist trećega, no za to je potrebno takvo izričito očitovanje ugovornih strana. ${ }^{19}$

Pokroviteljske izjave redovito se uspoređuju s jamstvom. ${ }^{20}$ Pored navedenih razlika (usmjerenosti na rezultat i kvalifikacija kao nepravi ugovor u korist trećega), pokroviteljske izjave i jamstvo imaju i dodirnih točaka. Tim je poslovima svojstvena određena razina akcesornosti obveze davatelja osiguranja prema osiguranoj obvezi dužnika koju ovaj duguje vjerovniku ili primatelju osiguranja. Pod akcesornošću redovito se podrazumijeva ovisnost obveze iz jednog posla o sadržaju, postojanju, utuživosti i opsegu obveze iz drugog posla. ${ }^{21} \mathrm{Za}$ razliku od jamstva, akcesornost kod pokroviteljskih izjava ograničena je na postojanje osigurane obveze. ${ }^{22}$ Tako u slučaju nepostojanja osigurane obveze (npr. jer osigurana obveza nije nastala, jer je ništetna ili jer ju je treći već ispunio pa je prestala) pokrovitelj može primatelju izjave istaknuti prigovor u cilju odbijanja njegova zahtjeva za ispunjenjem obveze pomaganja. Takva se akcesornost, međutim, ne odnosi na sadržaj i opseg predmeta osigurane obveze. ${ }^{23}$ Pokrovitelj se, naime, obvezuje općenito pomoći trećoj osobi kako bi ona bila imovinski u poziciji sama uredno ispuniti osiguranu obvezu. Tako apstraktno određena „pomoć“ ne mora sadržajno, a ni svojom visinom ni opsegom odgovarati predmetu

17 Tako općenito o nepravom ugovoru u korist trećega vidi Bilić, A., Ugovor u korist trećega, Zbornik Pravnog fakulteta u Zagrebu, 6 (2011), str. 1977-1978, 1983, 2008. U pogledu kvalifikacije pokroviteljske izjave kao nepravog ugovora u korist trećega vidi Koch, J., op. cit. u bilj. 3., str. 109. 133; Horn, J., op. cit. u bilj. 1., str. 175, 177-178, 180; La Corte, N., op. cit. u bilj. 9., str. 202; Bollenberger, R., Kellner, M., op. cit. u bilj. 1., Rbr. 4/31; Schnellecke, C., op. cit. u bilj. 1., str. 23-24; Kisser, J., op. cit. u bilj. 3., Rbr. 3.4.4; Tödter, C., op. cit. u bilj. 6., str. 41.

18 Tako bi, primjerice, u slučaju stečaja treće osobe takvo potraživanje moglo unovčiti, pri čemu bi se moglo postaviti i pitanje mjere unovčenja takvog potraživanja s obzirom na to da ono nije ograničeno visinom osigurane obveze. Pored toga, treća osoba mogla bi i založiti takvo potraživanje čime bi se narušila svrha takve izjave kao sredstva osiguranja određenog vjerovnika i određenog potraživanja. U tom smjeru sa stajališta njemačke pravne književnosti vidi Koch, J., op. cit. u bilj. 3., str. 132-133; Horn, J., op. cit. u bilj. 1., str. 178; La Corte, N., op. cit. u bilj. 9., str. 203-204.

19 Tako vidi La Corte, N., op. cit. u bilj. 9., str. 204.

20 Tako, primjerice, vidi Schnellecke, C., op. cit. u bilj. 1., str. 62-64.

21 U tom smjeru sa stajališta ugovora o jamstvu vidi Jakšić, T., Ugovor o jamstvu, doktorska disertacija, 2015. Zagreb, str. 26; Horn, N., u: Mansel, H. J., von Staudingers Kommentar zum Bürgerlichen Gesetzbuch mit Einführungsgesetz und Nebengesetzen, Buch 2., Recht der Schuldverhältnisse, §§ 765-778 (Bürgschaft), 14. Aufl., Neubearbeitung, 2013., Berlin, Vorbem zu §§765-778. BGB Rbr. 18; Schnellecke, C., op. cit. u bilj. 1., str. 25-26.

22 Tako vidi Koch, J., op. cit. u bilj. 3., str. 116, 257; Bollenberger, R., Kellner, M., op. cit. u bilj. 1., Rbr. 4/62. U tom smjeru vidi Schnellecke, C., op. cit. u bilj. 1., str. 26-27; La Corte, N., op. cit. u bilj. 9., str. 151-152.

23 Tako u pogledu sadržaja predmeta obveze vidi Koch, J., op. cit. u bilj. 3., str. 116, 123; Bollenberger, R., Kellner, M., op. cit. u bilj. 1., Rbr. 4/34, 4/62. U tom smjeru vidi Schnellecke, C., op. cit. u bilj. 1., str. 64; La Corte, N., op. cit. u bilj. 9., str. 300, 302. 
osigurane obveze. ${ }^{24}$ Iako je pokrovitelj ovlašten protiv primateljeva zahtjeva na ispunjenje obveze pomaganja isticati prigovore iz osiguranog posla kojima se osporava postojanje tog zahtjeva, to se nužno ne odnosi i na prigovore koji onemogućuju ili odgađaju ostvarenje tog zahtjeva (npr. prigovor zastare osigurane obveze). Isticanje takvih prigovora redovito ovisi o tome je li treća osoba sama istaknula takav prigovor primatelju izjave. ${ }^{25}$ To znači kako pokrovitelj snosi rizik neisticanja prigovora koji onemogućuju ili odgađaju ostvarenje vjerovnikova zahtjeva. Pokrovitelj, međutim, nije ograničen $u$ isticanju prigovora koji svoju osnovu imaju u samoj izjavi (npr. prigovor ništetnosti pokroviteljske izjave).

Razlika u odnosu na jamstvo postoji i u tomu što obveza pokrovitelja nije supsidijarna jer njezino ispunjenje vremenski redovito prethodi ispunjenju osigurane obveze treće osobe. ${ }^{26} \mathrm{~S}$ druge strane, jamčeva obveza može biti supsidijarna zbog čega će njeno ispunjenje vremenski nastupiti tek ako glavni dužnik uredno ne ispuni osiguranu obvezu. ${ }^{27}$ Osim toga, jamac odgovara za sposobnost glavnog dužnika na ispunjenje osigurane obveze, ali i postojanje njegove volje (spremnosti) za takvim ispunjenjem (neovisno o sposobnosti), pokrovitelj odgovara samo za sposobnost treće osobe na ispunjenje osigurane obveze. ${ }^{28}$

Pokroviteljske izjave teže sprječavanju neurednog ispunjenja osigurane obveze treće osobe. ${ }^{29}$ Takva preventivna funkcija nije nužno svojstvo i drugih poslova osiguranja. Tako je jamstvo usmjereno na neposredno ispunjenje osigurane obveze vjerovniku kada to ne učini glavni dužnik, a garancija na isplatu ugovorene odštete $u$ slučaju dužnikova neispunjenja osigurane obveze ili neke druge ugovorene povrede. Konačno, kod drugih osiguranja sadržaj predmeta obveze redovito je konkretno određen (npr. kao plaćanje određenog novčanog iznosa ili ispunjenje određene nenovčane činidbe), dok je kod pokroviteljskih izjava određenje konkretnog sadržaja predmeta obveze prepušteno pokrovitelju. ${ }^{30}$

24 Više o tome vidi ,3. Opseg predmeta obveze“.

25 Više o tome vidi La Corte, N., op. cit. u bilj. 9., str. 153-157. Više o podjeli prigovora na prigovore kojima se osporava postojanje zahtjeva primatelja izjave na ispunjenje preuzete obveze i prigovore koji onemogućuju ili odgađaju ostvarenje vjerovnikova zahtjeva vidi Jakšić, T., op. cit. u bilj. 21., str. 215; Markovinović, H., Ugovor o cesiji, doktorska disertacija, 2005. Zagreb, str. 220; Larenz, K., Wolf, M., Allgemeiner Teil des Bürgerlichen Rechts, 9. Aufl., 2004., München, $\$ 18$ Rbr. 42-66.

26 Tako vidi La Corte, N., op. cit. u bilj. 9., str. 133, 302. U tom se ogleda i preventivna funkcija pokroviteljskih izjava, više o tome u nastavku teksta.

27 U tom smjeru sa stajališta jamstva vidi Jakšić, T., op. cit. u bilj. 21., str. 30. U tom smjeru sa stajališta pokroviteljske izjave vidi Koch, J., op. cit. u bilj. 3., str. 115; Bollenberger, R., Kellner, M., op. cit. u bilj. 1., Rbr. 4/34.

28 Tako vidi i Schnellecke, C., op. cit. u bilj. 1., str. 63-64. U tom smjeru vidi Horn, J., op. cit. u bilj. 1., str. 197.

29 Tako vidi Koch, J., op. cit. u bilj. 3., str. 120; Schnellecke, C., op. cit. u bilj. 1., str. 30; Bollenberger, R., Kellner, M., op. cit. u bilj. 1., Rbr. 4/35.

30 Tako vidi Koch, J., op. cit. u bilj. 3., str. 120-121; Horn, J., op. cit. u bilj. 1., str. 175; La Corte, N., op. cit. u bilj. 9., str. 300, Bollenberger, R., Kellner, M., op. cit. u bilj. 1., Rbr. 4/35. 


\section{SADRŽAJ PREDMETA OBVEZE}

Čvrstom pokroviteljskom izjavom preuzima se uopćena obveza materijalnog pomaganja treće osobe radi njezina urednog ispunjenja osigurane obveze primatelju izjave. Redovito korišteni izrazi pokroviteljskih izjava, kao što je „pomaganje“, „podupiranje“ $i$,,vođenje brige“, tumače se tako kroz prizmu cilja koji se tim poslom želi postići. ${ }^{31}$ To znači kako se preuzeta obveza pomaganja može izvršiti na bilo koji način koji će trećoj osobi omogućiti uredno ispunjenje osigurane obveze. ${ }^{32}$ Težište obveze pomaganja, za razliku od obveza s određenijom činidbom, nije stoga u poduzimanju određene činidbe, već u poduzimanju jedne ili više činidbi koje će samostalno ili zajedno dovesti do ostvarenja željenog rezultata, tj. urednog ispunjenja osigurane obveze od strane treće osobe.

Kada se danoj izjavi obećana pomoć kvalificira kao „financijska“ ili „kapitalna“, to ne znači kako se ona može pružiti samo uplatom novca, uplatom iznosa u vlastiti kapital društva ili uplatom uloga u temeljni kapital treće osobe. Kako sadržaj predmeta pokroviteljeve obveze valja razmatrati kroz ciljani rezultat tog posla (uredno ispunjenja osigurane obveze treće osobe), valja zaključiti kako je ispunjenje te obveze moguće učiniti na bilo koji način kojim se on postiže. ${ }^{33}$ Primatelja izjave u pravilu zanima samo uredno ispunjenje osigurane obveze, a ne i kako je pokrovitelj pridonio ispunjenju, a niti je li uopće pridonio ispunjenju ako treća osoba samostalno ispuni tu obvezu. Pokroviteljske izjave stoga karakterizira diskrecijsko pravo pokrovitelja vezano uz izbor načina i sadržaja ispunjenja obveze pomaganja treće osobe. Hoće li pokrovitelj pomoći treću osobu novčano ili nenovčano, isključivo je na pokrovitelju uz uvjet da takvo „pomaganje“ rezultira urednim ispunjenjem osigurane obveze. ${ }^{34}$

Osim (redovito) uplatom novčanih sredstava, obveza pomaganja može se ispuniti i prijenosom odnosno davanjem na korištenje drugih materijalnih sredstava (npr. izuma, poduzeća, proizvodnih pogona, robe i drugih stvari). Treća osoba koristi takva sredstva za jačanje svoje likvidnosti i rentabilnosti poslovanja, a sve radi stvaranja okolnosti za uredno ispunjenje osigurane obveze. Pružanje takve pomoći može biti prikladno pokrovitelju i trećoj osobi koje se bave istim ili povezanim

31 U tom smjeru vidi La Corte, N., op. cit. u bilj. 9., str. 83; Bollenberger, R., Kellner, M., op. cit. u bilj. 1., Rbr. 4/37. Pobijanje ugovora zbog zablude glede značaja takvih uobičajenih izraza kao izraza koji dovode do preuzimanja obveze pomaganja treće osobe moguće je samo u iznimnim slučajevima. Tako vidi La Corte, N., op. cit. u bilj. 9., str. 84.

32 Tako vidi Koch, J., op. cit. u bilj. 3., str. 140-141; La Corte, N., op. cit. u bilj. 9., str. 122. U tom smjeru vidi Kisser, J., op. cit. u bilj. 3., Rbr. 3.4.2. Takva se obveza može kvalificirati kao alternativna obveza prema odredbi čl. 32. ZOO-a (njem. Wahlschuld). Međutim, obveza pomaganja treće osobe tada nije određena, već odrediva, a njezino je konačno određenje prepušteno pokrovitelju. Takvo uređenje pruža pokrovitelju visok stupanj diskrecije vezano uz izbor načina ispunjenja osigurane obveze.

33 Tako vidi Koch, J., op. cit. u bilj. 3., str. 141; Schnellecke, C., op. cit. u bilj. 1., str. 22, 29-30; La Corte, N., op. cit. u bilj. 9., str. 121-123; Bollenberger, R., Kellner, M., op. cit. u bilj. 1., Rbr. $4 / 20$.

34 Tako vidi Koch, J., op. cit. u bilj. 3., str. 141-142; Bollenberger, R., Kellner, M., op. cit. u bilj. 1., Rbr. 4/42. U tom smjeru vidi Horn, J., op. cit. u bilj. 1., str. 183. 
gospodarskim djelatnostima (npr. kao sudionici horizontalnog koncerna). ${ }^{35}$ Predaja nenovčanih sredstava redovito je u interesu pokrovitelja jer mu omogućuje očuvanje vlastite likvidnosti. Treća osoba, s druge strane, mora biti u stanju koristiti tako dobivena sredstva na način koji u vrijeme dospijeća osigurane obveze dovodi do njezina urednog ispunjenja. Ako treća osoba u trenutku pružanja pomoći nema na raspolaganju potrebna likvidna sredstva za namirenje tekućih obveza, nije izgledno ni kako će biti u stanju odgovarajuće iskoristiti dobivena nenovčana (nelikvidna) sredstva ${ }^{36} \mathrm{U}$ takvoj situaciji, sadržaj pokroviteljeve pomoći valja ograničiti na predaju novčanih sredstva jer samo takva pomoć može dovesti do urednog ispunjenja osigurane obveze. Naravno, može se raditi i o kombinaciji likvidnih i nelikvidnih sredstava ako je iznos likvidnih sredstava dostatan za aktivaciju postojeće imovine i ostalih dobivenih sredstava u svrhe urednog ispunjenja osigurane obveze (npr. za pokrivanje troškova pokretanja proizvodnje i plasiranje robe na tržište radi njezine prodaje). Pokroviteljeva odluka o pružanju nenovčanih sredstava ovisi stoga o procjeni imovinskog stanja treće osobe i njezine mogućnosti preoblikovanja dobivene pomoći u sredstva koja će dovesti do urednog ispunjenja osigurane obveze. ${ }^{37} \mathrm{Za}$ donošenje takve odluke ne treba uzeti u obzir samo faktične mogućnosti iskorištavanja takvih sredstava od treće osobe, već $\mathrm{i}$ to hoće li, s obzirom na vrijeme dospijeća osigurane obveze, treća osoba imati dovoljno vremena za pribavljanje potrebnih sredstava za uredno ispunjenje osigurane obveze. Pokrovitelju je u interesu ispitati takve mogućnosti treće osobe jer ako pruži pomoć, a treća osoba potom ne bude u stanju uredno ispuniti osiguranu obvezu zbog neprimjerenosti dobivene pomoći, pokrovitelj će odštetno odgovarati primatelju izjave zbog neurednog ispunjenja svoje obveze. ${ }^{38}$ Takvo ispitivanje redovito se postiže uspostavom dužnosti obavještavanja treće osobe koja će pokrovitelju omogućiti donošenje pravodobne i informirane odluke o sadržaju i načinu pružanja pomoći. ${ }^{39}$

Sadržaj predmeta obveze pomaganja redovito biva i predmetom uređenja unutarnjeg odnosa pokrovitelja i treće osobe. Tim se odnosom pokrovitelj obvezuje, uz ugovorene uvjete, staviti na raspolaganje određena materijalna sredstva trećoj osobi

35 Tako vidi Koch, J., op. cit. u bilj. 3., str. 143-144.

36 Tako, primjerice, ako treća osoba nema likvidnih sredstava za uredno podmirenje redovnih troškova proizvodnje (npr. plaća radnika, režije i hladni pogon), nije izgledno kako će biti u stanju iskoristiti sirovinu dobivenu od pokrovitelja radi proizvodnje robe i njezina plasiranja na tržište za likvidna sredstva.

37 Tako vidi Koch, J., op. cit. u bilj. 3., str. 144; La Corte, N., op. cit. u bilj. 9., str. 123. U tom smjeru vidi Bollenberger, R., Kellner, M., op. cit. u bilj. 1., Rbr. 4/44.

38 U tom smjeru vidi Koch, J., op. cit. u bilj. 3., str. 144-145.

39 U pravilu neće biti problema kada se radi o društvima koncerna, opasnost donošenja neinformirane odluke postojat će, međutim, kada se radi o nepovezanim društvima koja svoj međusobni odnos tek moraju urediti. Pokrovitelj tada može pri uređenju tog odnosa inzistirati na uspostavi određene dužnosti obavještavanja na strani treće osobe. Rijetke su situacije u kojima se pokrovitelj obvezuje pomoći treću osobu s kojom na neki način već nije povezan, no tada se odgovarajuća uspostava dužnosti obavještavanja može uvjetovati davanjem same pomoći i povoljnijim uvjetima pružanja takve pomoći od pokrovitelja (npr. povoljnijom kamatnom stopom na iznos zajma ili kredita, ugovaranjem jednostranog prava na raskid pokrovitelja ili ugovorne kazne). 
radi ispunjenja osigurane obveze, dok se treća osoba obvezuje uz ugovorene (redovito povoljnije) uvjete vratiti tako dobivena sredstva. Kada se radi o novčanim sredstvima, odnos pokrovitelja i treće osobe po svojoj pravnoj naravi redovito odgovara zajmu. ${ }^{40}$ Ovisno o sadržaju predmeta pomoći, takav odnos može biti uređen i drukčije (npr. kao ugovor o licenciji, ugovor o vođenju poslova, ugovor o prepuštanju poduzeća ili pogona te ugovor o djelomičnom prijenosu dobiti). Pokroviteljskom izjavom treća osoba se ne može prisiliti na uređenje odnosa pomaganja s pokroviteljem, zbog čega se takve izjave redovito izdaju u korist društava koja su na neki način već povezana s pokroviteljem. ${ }^{41} \mathrm{Ne}$ uspije li pokrovitelj urediti odnos s trećom osobom kao zajam ili neki drugi naplatni posao, pruženu pomoć može klasificirati i kao darovanje. ${ }^{42}$ Osim toga, osoba koje će pružiti pomoć (npr. zajmodavac) ne mora biti nužno i pokrovitelj. Pokrovitelj se tada redovito javlja kao osoba koja potiče zajmodavca na davanje zajma trećoj osobi (npr. zajmodavac može biti pokroviteljevo društvo kćer, banka ili poslovni partner). ${ }^{43}$ Posao s naslova kojeg se trećoj osobi osiguravaju novčana sredstva radi ispunjenja osigurane obveze ne mora biti između pokrovitelja i treće osobe, to može biti i posao pokrovitelja u kojoj treća osoba ima svojstvo stjecatelja ili primatelja neke ugovorene koristi (npr. ispunjenja s naslova naloga, zajma u korist treće osobe ili drugog sličnog posla u korist treće osobe).

Obveza pomaganja može se ispuniti i dokapitalizacijom društva treće osobe. ${ }^{44}$ Kod društava kapitala to će biti redovito efektivnim povećanjem temeljnoga kapitala društva pri čemu imovina koju pokrovitelj unese u društvo odgovara njegovu ulogu u temeljni kapital društva. ${ }^{45}$ Kod takvog pomaganja treća osoba stječe sredstva

40 Tako vidi Koch, J., op. cit. u bilj. 3., str. 143.

41 U tom smjeru vidi Kisser, J., op. cit. u bilj. 3., Rbr. 1.4. Takva povezanost redovito omogućuje korištenje utjecaja (bilo od pokrovitelja, treće osobe ili društva majke pokrovitelja i treće osobe) koji omogućuje odgovarajuće uređenje odnosa pokrovitelja i treće osobe. Neovisno o tomu je li došlo do uređenja takvog unutarnjeg odnosa pokrovitelja i treće osobe, pokrovitelj ostaje obvezan prema primatelju izjave i morat će ispuniti preuzetu obvezu pomaganja treće osobe. Ako treća osoba onemogućuje i otežava primanje takve pomoći radi urednog ispunjenja osigurane obveze, pokrovitelju uvijek ostaje mogućnost ispunjenja osigurane obveze izravno primatelju izjave. Više o tome vidi „4. Pravo pokrovitelja na ispunjenje osigurane obveze izravno primatelju izjave“.

42 U tom smjeru vidi Bollenberger, R., Kellner, M., op. cit. u bilj. 1., Rbr. 4/43. Više o mogućnosti regresa pokrovitelja vidi „4. Pravo pokrovitelja na ispunjenje osigurane obveze izravno primatelju izjave“.

43 Tako vidi Schnellecke, C., op. cit. u bilj. 1., str. 30. U takvom odnosu pokrovitelj redovito osigurava uredno vraćanje zajma treće osobe (npr. kao jamac, kao založni dužnik ili fiducijarnim prijenosom vlasništva).

44 Tako vidi Schnellecke, C., op. cit. u bilj. 1., str. 30; Kisser, J., op. cit. u bilj. 3., Rbr. 3.4.2.

45 Tako, primjerice, vidi odredbu čl. 305. Zakona o trgovačkim društvima (NN, br. 111/93, 34/99, 121/99, 52/00, 118/03, 107/07, 146/08, 137/09, 125/11, 111/12, 68/13 i 110/15, dalje: ZTD) o pretpostavkama za povećanje temeljnoga kapitala društva te odredbu čl. 306. ZTD-a o povećanju temeljnog kapitala unosom stvari i prava kod dioničkog društva. Kod društva s ograničenom odgovornošću vidi odredbu čl. 457. ZTD-a o povećanju temeljnoga kapitala novim uplatama. Više općenito o povećanju temeljnoga kapitala ulozima kod dioničkog društva vidi Barbić, J., Pravo društava, Knjiga druga, Društva kapitala, Svezak I., 6. izd., 2013., Zagreb, str. 1266-1286. Više općenito o povećanju temeljnog kapitala ulozima kod društva s ograničenom odgovornošću vidi Barbić, J., Pravo društava, Knjiga druga, Društva kapitala, 
potrebna za uredno ispunjenje osigurane obveze, a pokrovitelj stječe zauzvrat dionice ili poslovne udjele u društvu treće osobe. Takvo pružanje pomoći dolazi u obzir samo ako se povećanje može provesti do dospijeća osigurane obveze. Drugim riječima, ako od trenutka donošenja odluke o pružanju takve pomoći do dospijeća osigurane obveze ne bude dovoljno vremena za provedbu postupka povećanja temeljnoga kapitala i učinkovito korištenje tako stečenih sredstava radi urednog ispunjenja osigurane obveze, pokrovitelj ne može ispuniti svoju obvezu pomaganja na taj način. ${ }^{46}$ Kod društava kapitala obveza pomaganja može se izvršiti i preko instituta dodatnih obveza kod dioničkog društva odnosno dodatnih činidbi i dodatnih plaćanja kod društva s ograničenom odgovornošću. ${ }^{47}$ Kod takvih pravnih radnji treba, međutim, imati na umu zakonska ograničenja koja takvo pomaganje mogu učiniti manje praktičnim. ${ }^{48}$

Radi li se o društvima osoba, za obveze treće osobe, uključivo i osigurane obveze prema primatelju izjave, pokrovitelj već odgovara solidarno i neograničeno cijelom svojom imovinom. ${ }^{49}$ Osobna sredstva osiguranja gube na važnosti kada su davatelji tih osiguranja ujedno i članovi društva u čiju korist takvo osiguranje biva preuzeto.

\section{OPSEG PREDMETA OBVEZE}

Kako bi pokrovitelj znao koliko je dužan pomoći treću osobu radi ispunjenja svoje obveze uz pokroviteljske izjave mora znati mjeru takve obveze. U određenju opsega pokroviteljeve obveze valja poći od cilja koji se želi postići takvim ispunjenjem jer opseg pokroviteljeve obveze nije obuhvaćen akcesornošću prema osiguranoj obvezi. To znači kako je pokrovitelj dužan pomoći treću osobu u mjeri koja će dovesti do njegova urednog ispunjenja osigurane obveze primatelju izjave. ${ }^{50}$ Opseg pokroviteljeve obveze stoga ne zavisi o opsegu osigurane obveze, mjera njegove pomoći trećoj osobi može biti manja, ali i veća od te obveze. Tako će, primjerice, biti manja ako treća osoba raspolaže vlastitim sredstvima, ali nedovoljno za samostalno

Svezak II., 6. izd., 2013., Zagreb, str. 495-507.

46 Tako vidi Koch, J., op. cit. u bilj. 3, str. 145. To ne znači kako se naknadno ne bi mogle steći dionice tog društva, primjerice, s naslova zamjene obveznica društva za dionice društva, naknadnim unosom tog potraživanja kao uloga u postupku povećanja temeljnog kapitala društva ili zamjenom potraživanja prema društvu za vlastite dionice društva. Tada pokrovitelj gubi regresni zahtjev prema trećoj osobi. Tako vidi Bollenberger, R., Kellner, M., op. cit. u bilj. 1., Rbr. $4 / 80$.

47 Tako, primjerice, vidi odredbu čl. 218. ZTD-a o dodatnim obvezama dioničara te odredbu čl. 391. ZTD-a o dodatnim činidbama i dodatnim plaćanjima.

48 Naime, takve dodatne obveze može učiniti samo član društva koji se na to obvezao temeljnim aktom društva. Ako pokrovitelj nije član koji se obvezao na takva dodatna činjenja, ne postoji ni obveza prema trećoj osobi na takvo pomaganje. Pored toga, takva dodatna činjenja zakonom su ograničena i na druge načine pa se tako, primjerice, kod dioničkog društva dodatna obveza može sastojati samo u nenovčanoj činidbi, a takva obveza može biti vezana samo uz vinkulirane dionice koje izdaju u materijaliziranom obliku (čl. 218. st. 1. ZTD). Unatoč iznesenim ograničenjima, prednost je što se može ugovoriti naplatno ispunjenje takvih dodatnih obveza.

49 Tako vidi odredbu čl. 94. st. 1. ZTD.

50 Tako vidi La Corte, N., op. cit. u bilj. 9., str. 131; Kisser, J., op. cit. u bilj. 3., Rbr. 3.4.1.2., 3.4.1.4. 
uredno ispunjenje osigurane obveze. S druge strane, pokroviteljeva obveza opsegom može biti i veća kada, primjerice, pružena sredstva pomoći budu zahvaćena ovršnih zahtjevom nekog drugog vjerovnika zbog čega treća osoba preostalim sredstvima neće više moći imovinski uredno ispuniti ovršenu obvezu i osiguranu obvezu. Pokrovitelj je tada dužan pomoći treću osobu u mjeri koja otklanja takvu nesposobnost plaćanja i ponovno uspostavlja mogućnost njezina urednog ispunjenja osigurane obveze.

Nema dvojbe kako se osiguranje može ograničiti samo na ispunjenje određene ili odredive obveze, više određenih ili odredivih obveza, ali i jedne ili više sporednih obveza treće osobe kao glavnog dužnika. ${ }^{51}$ Naspram drugih osiguranja (npr. jamstva), jasno određenje osigurane obveze manje je važno kod pokroviteljskih izjava jer su takva osiguranja usmjerena na postizanje određenog rezultata. S obzirom na osiguravajuću funkciju, preuzimanje obveze pomaganja radi urednog ispunjenja osigurane obveze treće osobe podrazumijeva i pružanje pomoći u pogledu ispunjenja glavne i svih sporednih obveza koje se redovito vežu uz taj posao. ${ }^{52}$ Uz određeni posao redovito se vežu one sporedne obveze koje su tipične za takav pravni posao (npr. obveza plaćanja kamata kod ugovora o kreditu). Želi li pokrovitelj, međutim, ograničiti obvezu pomaganja samo na glavnu ili neku sporednu obvezu, takvo ograničenje mora jasno izraziti danom izjavom. ${ }^{53}$ Pružanjem pomoći radi ispunjenja neke sporedne obveze treće osobe pokrovitelj redovito pomaže i ispunjenje njezine cjelokupne obveze (glavne i sporedne). To je stoga što nemogućnost urednog ispunjenja sporedne obveze od strane treće osobe redovito povlači i nemogućnost njezina urednog ispunjenja glavne obveze. ${ }^{54}$

Pokroviteljske izjave sadrže i izričaje kojima se pokrovitelj „uvijek“ ili „svakodobno“ obvezuje uzdržavati financijsku opstojnost treće osobe. Tada se nameće pitanje obvezuje li tako sročena izjava pokrovitelja na pomaganje treće osobe radi ispunjenja obveza prema svim njezinim vjerovnicima, dakle i potraživanja koja ne pripadaju primatelju izjave? Takvim izričajem redovito ne nastaje takva univerzalna (globalna) obveza održavanja likvidnosti odnosno pomaganja treće osobe u pogledu

51 Tako, primjerice, sporedna obveza može biti obveza plaćanja ugovornih i zateznih kamata, obveza plaćanja različitih naknada (npr. transakcijskih), ali i obveza naknađivanja štete zbog povrede ugovora.

52 U tom smjeru vidi Koch, J., op. cit. u bilj. 3., str. 146-147.

53 U ovom pogledu upućuje se na odgovarajuću primjenu pravila koja vrijede za ugovor o jamstvu. Tako vidi Koch, J., op. cit. u bilj. 3., str. 147. U pogledu ugovora o jamstvu u ovom smislu vidi Jakšić, T., op. cit. u bilj. 21., str. 96, 98-99.

54 Iznesenom stajalištu ide u prilog i odredba čl. 172. ZOO-a o uračunavanju ispunjenja kamata i troškova. Prema toj odredbi, ako dužnik duguje pored glavnice kamate i troškove, prvo se namiruju troškovi, zatim kamate, a tek nakon toga glavnica. Drugim riječima, ispunjenje takvih sporednih obveza (troškova i kamata) ima prednost pred ispunjenjem glavne obveze (glavnice). Problem nastaje kada se osiguranje pruži samo radi ispunjenja glavne obveze, a ne i drugih sporednih obveza treće osobe (npr. osiguranje za plaćanje glavnice kredita, a ne i dospjelih ugovorenih kamata). Tada, imajući u vidu iznesena pravila o uračunavanju ispunjenja, redovito nije moguće pomaganje treće osobe samo vrijednošću koja odgovara vrijednosti osigurane glavnice jer se primjenom iznesenih pravila, prvo namiruju sporedna potraživanja, a onda glavnica. To ne znači kako pokrovitelj ne bi mogao isplatiti glavnicu izravno vjerovniku i time se osloboditi svoje obveze s naslova pokroviteljske izjave. Više o tome vidi poglavlje „4. Pravo pokrovitelja na ispunjenje osigurane obveze izravno primatelju izjave“. 
potraživanja svih njezinih vjerovnika. ${ }^{55}$ To ne znači kako ranija nesposobnost ispunjenja obveze treće osobe prema drugom vjerovniku ne može dovesti i do nesposobnosti ispunjenja osigurane obveze koja kasnije dospijeva. Takva univerzalna obveza redovito nije $\mathrm{u}$ interesu pokrovitelja, a ni $\mathrm{u}$ interesu primatelja izjave. ${ }^{56}$ Gospodarski značaj pokroviteljske izjave očituje se upravo kroz zaštitu primateljeva interesa za urednim namirenjem određenog potraživanja prema trećoj osobi. Pristajući na takvo osiguranje primatelj izjave svjestan je rizika potpune ili djelomične nemogućnosti urednog namirenja svojeg potraživanja prema trećoj osobi, jer mu u suprotnom ni ne bi bilo potrebno takvo osiguranje. Kao i kod jamstva, pokroviteljskom izjavom treća osoba i pokrovitelj stoje iza ispunjenja osigurane obveze svojim imovinskim masama. To ne znači kako pokrovitelj ne smije pomagati treću osobu radi održavanja njezine opće likvidnosti, a sve kako bi ona bila u stanju uredno ispuniti osiguranu obvezu primatelju izjave. Štoviše, takvo pomaganje treće osobe redovito će i biti potrebno u slučaju njezine prijeteće nesposobnosti plaćanja i prezaduženosti prije dospijeća osigurane obveze. Takvo što, međutim, ne daje primatelju izjave, a ni bilo kojem drugom vjerovniku treće osobe, pravo na postavljanje zahtjeva pokrovitelju za pomaganjem treće osobe usmjerenim isključivo na ispunjenje neosiguranog potraživanja. U slučaju povrede obveze pomaganja, interes primatelja izjave zaštićen je i mogućnošću postavljanja odštetnog zahtjeva prema pokrovitelju. ${ }^{57}$

\section{PRAVO POKROVITELJA NA ISPUNJENJE OSIGURANE OBVEZE IZRAVNO PRIMATELJU IZJAVE}

Kada treća osoba dobije potrebna sredstva od pokrovitelja za uredno ispunjenje osigurane obveze postoji opasnost zlouporabe dobivenih sredstava od treće osobe $\mathrm{u}$ svrhu koja ne služi urednom ispunjenju osigurane obveze. Moguće su i situacije u kojima nema takve zlouporabe, a treća osoba, unatoč pruženoj pomoći, nema dovoljno sredstava za uredno ispunjenje osigurane obveze (npr. zbog nastale nesposobnosti plaćanja ili provedene ovrhe na dobivenim sredstvima). Tada i dalje postoji obveza pokrovitelja na pomaganje treće osobe radi njena urednog ispunjenja osigurane obveze..$^{58}$ Uzme li se u obzir kako tako dobivena dodatna sredstva mogu opet biti

55 Tako vidi La Corte, N., op. cit. u bilj. 9., str. 125-126; Bollenberger, R., Kellner, M., op. cit. u bilj. 1., Rbr. 4/40.

$56 \mathrm{~S}$ jedne strane, pokrovitelju će preuzimanje takvog univerzalnog osiguranja biti redovito otegotno, dok će primatelju izjave također biti u interesu da ima osiguranje koje će mu omogućiti uredno namirenje njegova osiguranog potraživanja prema trećoj osobi. Preuzimanje univerzalnog osiguranja, s druge strane, može dovesti i do stečaja, a potom i prestanka osobe pokrovitelja prije negoli je potraživanje primatelja izjave uopće došla na naplatu. To ne znači kako se takva univerzalna obveza održavanja likvidnosti ne bi mogla izričito preuzeti, primjerice, objavom u javnim medijima ili financijskim te poslovnim izvješćima društva. Tada se nameće pitanje i kvalifikacije takvog osiguranja, npr. radi li se možda o osiguranju koje ima učinak izjave o pristupanju dugu prema odredbi čl. 124. Stečajnog Zakona (NN, br. 71/15, dalje: SZ). Više o takvoj obvezi i njezinu preuzimanju sa stajališta njemačke pravne književnosti vidi La Corte, N., op. cit. u bilj. 9., str. 84-86, 126; Tödter, C., op. cit. u bilj. 6., str. 42-44.

57 U tom smjeru vidi Koch, J., op. cit. u bilj. 3., str. 163.

58 Tako vidi Koch, J., op. cit. u bilj. 3., str. 165-167; Horn, J., op. cit. u bilj. 1., str. 180-181; 
iskorištena u neke druge svrhe ili ovršena od drugih vjerovnika, proizlazi kako obveza pomaganja treće osobe može za pokrovitelja predstavljati, tzv. ,rupu bez dna““. ${ }^{9}$

Shodno tomu, nameće se pitanje može li pokrovitelj ispuniti svoju obvezu na način kojim će izbjeći takav rizik potrebe dodatnog pomaganja treće osobe? Takav rizik pokrovitelj može izbjeći ispunjenjem osigurane obveze izravno primatelju izjave. Pokroviteljske izjave su najprikladnije kada pokrovitelj može ostvarivanjem utjecaja i nadzora nad trećom osobom biti siguran kako će pružena pomoć biti iskorištena za namirenje osigurane obveze. Primatelju izjave u pravilu je bitno samo uredno ispunjenje njegova potraživanja, a hoće li mu osigurano potraživanje ispuniti njegov dužnik (treća osoba) ili neka druga osoba (npr. pokrovitelj), redovito mu nije važno. ${ }^{60}$ Preuzimanje pokroviteljske izjave umjesto nekog neposrednijeg i jačeg sredstva osiguranja (npr. jamstva) redovito je više u interesu pokrovitelja, pa je logično da se pokrovitelj može i odreći takvog načina ispunjenja kada je njegov interes za izravnim ispunjenjem osigurane obveze veći od obveze pomaganja. ${ }^{61}$ Pored toga, ne treba zaboraviti kako su pokroviteljske izjave usmjerene na postizanje određenog rezultata, tj. na uredno ispunjenje osigurane obveze treće osobe. Hoće li do ostvarenja tog rezultata doći pomaganjem treće osobe koja će potom sama ispuniti osiguranu obvezu ili pokroviteljevim ispunjenjem osigurane obveze, manje je relevantno ako takvo ispunjenje dovede do urednog ispunjenja osigurane obveze. Takvo izravno ispunjenje osigurane obveze moguće je ugovoriti pokroviteljskom izjavom. To je moguće i naknadno dogovoriti s primateljem izjave, no pokrovitelj može ispuniti osiguranu obvezu izravno primatelju izjave i s naslova odredbe članka 161. stavka 2. ZOO-a. Prema toj odredbi, vjerovnik je dužan primiti ispunjenje od svake osobe s pravnim interesom za ispunjenjem obveze, čak i kada se dužnik tomu protivi. ${ }^{62}$ Pokrovitelj ima takav interes jer neispunjenje ili neuredno ispunjenje

Schnellecke, C., op. cit. u bilj. 1., str. 33-34; La Corte, N., op. cit. u bilj. 9, str. 140; Bollenberger, R., Kellner, M., op. cit. u bilj. 1., Rbr. 4/39; Tödter, C., op. cit. u bilj. 6., str. 41.

59 Tako vidi Bollenberger, R., Kellner, M., op. cit. u bilj. 1., Rbr. 4/53. U tom smjeru vidi La Corte, N., op. cit. u bilj. 9., str. 138-139, 144; Kisser, J., op. cit. u bilj. 3., Rbr. 3.4.3.

60 Iznimke su moguće kada postoji dodatni interes primatelja izjave za pružanjem pomoći trećoj osobi (npr. kada je njegov poslovni partner ili povezano društvo u drugom poslovnom odnosu $\mathrm{s}$ trećom osobom pa se pružena pomoć refleksno odražava i na njega). Tako vidi Bollenberger, R., Kellner, M., op. cit. u bilj. 1., Rbr. 4/54.

61 Tako vidi Koch, J., op. cit. u bilj. 3., str. 167-168, 276-277.

62 Prema njemačkom pravu vjerovnik teoretski može odbiti takvo izravno pokroviteljevo ispunjene osigurane obveze prema odredbi §267. BGB-a, no to će u praksi biti dopušteno samo ako se ne radi o djelovanju protivno načelu savjesnosti i poštenja (npr. protivno načelu venire contra factum proprium). Više o tome vidi Koch, J., op. cit. u bilj. 3, str. 171-172, 175; Horn, J., op. cit. u bilj. 1., str. 181; Schnellecke, C., op. cit. u bilj. 1., str. 34-35; La Corte, N., op. cit. u bilj. 9., str. 143-145. Prema austrijskom pravu, sukladno odredbi §1423. ABGB-a, za takvo ispunjenje potreban je pristanak treće osobe, no takav se pristanak ne može odbiti ako bi takvo odbijanje predstavljalo zlouporabu prava treće osobe. Tako vidi Bollenberger, R., Kellner, M., op. cit. u bilj. 1., Rbr. 4/58; Kisser, J., op. cit. u bilj. 3., Rbr. 3.4.5. Dio pravne književnosti zauzima stajalište kako pokrovitelj može izravno ispuniti svoju obvezu primatelju izjave umjesto ispunjenja obveze pomaganja trećoj osobi. Tada se smatra kako se radi o alternativnoj obvezi, prema kojoj pokrovitelj ima pravo izbora između ispunjenja obveze pomaganja treće te obveze izravnog ispunjenja osigurane obveze primatelju izjave ili ispunjenja neke druge 
osigurane obveze treće osobe može dovesti do odštetne odgovornosti pokrovitelja prema primatelju izjave. Sadržaj pokroviteljeva ispunjenja mora pritom odgovarati sadržaju predmeta osigurane obveze glavnog dužnika sukladno odredbi članka 166. stavka 1. ZOO-a, osim u slučaju zamjene ispunjenja s naslova odredbe članka 167. ZOO-a.$^{63}$ Ispunjenjem osigurane obveze pokrovitelj zakonski subrogira u prava i položaj primatelja izjave prema trećoj osobi s naslova odredbe članka 91. ZOO-a. To znači kako pokrovitelj tada može temeljem takve subrogacije regresno potraživati od treće osobe ono što je ispunio primatelju izjave kao vjerovniku. ${ }^{64} \mathrm{Za}$ razliku od jamstva, ovdje je opseg regresnog zahtjeva ograničen onime što pokrovitelj ispuni vjerovniku na ime ispunjenja osigurane obveze. ${ }^{65}$

Osim što se može poslužiti takvim izravnim ispunjenjem osigurane obveze, pokrovitelj može, radi izbjegavanja rizika potrebe dodatnog pomaganja treće osobe, ispuniti svoju obvezu s naslova pokroviteljske izjave i korištenjem bankovnog računa sa zaporkom. ${ }^{66}$ Imatelj računa sa zaporkom (pokrovitelj) i korisnik zaporke (primatelj izjave) ograničeni su u raspolaganju kontom računa onako kako je uređeno trostranim dogovorom s bankom. Kod pokroviteljske izjave to će najčešće biti ugovaranje mogućnosti raspolaganja saldom na takvom računu ako po dospijeću treća osoba uredno ne ispuni osiguranu obvezu. Ugovorne strane tog posla, međutim, mogu biti samo imatelj računa (pokrovitelj) i banka, pri čemu će takav odnos urediti kao ugovor u korist trećega (primatelja izjave). Sudjelovanje i pristanak banke važan je radi zaštite pokrovitelja jer se bez znanja banke takav račun tretira kao i svaki drugi račun čijim saldom slobodno raspolaže njegov imatelj (pokrovitelj). ${ }^{67}$ Saldo na računu sa zaporkom zaštićen je od ovršnih i stečajnih potraživanja vjerovnika treće osobe, ali ne

obveze primatelju izjave. Iako bi tada primatelj mogao odbiti ispunjenje koje sadržajno ne odgovara osiguranoj obvezi ili njegovu interesu, takvo odbijanje valja onemogućiti u slučaju zlouporabe primatelja izjave. Tako vidi Bollenberger, R., Kellner, M., op. cit. u bilj. 1., Rbr. $4 / 56,4 / 57$.

63 U poslovnoj praksi pokroviteljska izjava redovito se izdaje radi osiguranja novčanih činidbi (npr. s naslova zajma ili kredita) tako da su rijetki slučajevi zamjene ispunjenja.

64 U njemačkom i austrijskom pravu tada se ne radi o zakonskoj subrogaciji, već o institutu zakonske cesije (cessio legis). Njemačko i austrijsko pravo glede prijenosa osiguranog potraživanja s primatelja na pokrovitelja razlikuje se u odnosu na pravila hrvatskog prava, iako učinci takve cesije odgovaraju učincima zakonske subrogacije prema hrvatskom pravu. Više o tome sa stajališta njemačke pravne književnosti vidi Koch, J., op. cit. u bilj. 3., str. 170-171; Schnellecke, C., op. cit. u bilj. 1., str. 59. U tom smjeru sa stajališta austrijske pravne književnosti vidi Bollenberger, R., Kellner, M., op. cit. u bilj. 1., Rbr. 4/79. Više o općenito zakonskoj cesiji vidi Markovinović, H., op. cit. u bilj. 25., str. 61-62. Pritom valja naglasiti kako se povrat imovinskih sredstava pokrovitelju (,regres“) može postići i s naslova unutarnjeg odnosa pokrovitelja i treće osobe (npr. drugog zajma), a i pravila društva prava (npr. s naslova odredbe čl. 493. st. 1. ZTD o vođenju poslova u ovisnom društvu).

65 Opseg jamčeva regresa šire je uređen posebnim pravilima ugovora o jamstvu za razliku od opsega regresa prema općim pravilima o subrogaciji. Tako usporedi odredbu čl. 94. ZOO-a o opsegu ispuniteljeva regresa i odredbu čl. 120. ZOO-a o jamčevu regresu.

66 U tom smjeru vidi Koch, J., op. cit. u bilj. 3., str. 178-179.

67 Više o općenito pojmu računa sa zaporkom i ugovornom ograničenju raspolaganja saldom takvog računa vidi Miladin, P., Bankarski računi pravnih i fizičkih osoba, Pravo u gospodarstvu, (2005) br. 4, str. 156, 159-160. 
i od takvih potraživanja pokroviteljevih vjerovnika. To je stoga što primatelj izjave, kao korisnik, tada stječe samo obveznopravni zahtjev prema pokrovitelju, kao imatelju računa, a ne i pravo koje sprječava ovrhu odnosno namirenje stečajnih vjerovnika (izlučno ili razlučno pravo).$^{68}$ Ako je takav račun sa zaporkom uređen kao povjerenički račun čiji je imatelj primatelj izjave, pokrovitelj je, kao povjeritelj novčanih sredstava na računu, zaštićen od ovršnih zahtjeva primateljevih vjerovnika dok mu u slučaju stečaja na primatelje izjave valja priznati izlučno pravo na povjerenim sredstvima. ${ }^{69}$

Pored korištenja računa sa zaporkom moguće je i korištenje escrow računa. Kod bankovnog escrow računa jedna strana, kao nalogodavac banke, predaje novac banci, određene dokumente ili vrijednosne papire u polog, a raspolaganje tim sredstvima omogućeno je drugoj strani, kao korisniku, sukladno uvjetima koje sve strane prethodno odrede. ${ }^{70}$ Takav posao pogodan je kada je ispunjenje obveze jedne strane ugovoreno uz neki odgodni uvjet. U konkretnom slučaju, pokrovitelj se obvezuje kod banke položiti određeni novčani iznos, kao nalogodavac, a banka se obvezuje primatelju izjave, kao korisniku, omogućiti raspolaganjem saldom tog računa ako ne primi uredno ispunjenje osigurane obveze od treće osobe. Kod višekratnih obveza (npr. kada se radi o otplati kredita na rate), omjer primateljeva raspolaganja saldom računa ugovorno se ograničava na preostali iznos osigurane obveze koji nije uredno podmiren, dok se ostatak salda vraća na raspolaganje pokrovitelju. Kako se kod escrow računa radi o posebnu računu banke, uspješnost ovršnih zahtjeva primateljevih odnosno pokroviteljevih vjerovnika, odnosno zahtjeva stečajnih vjerovnika za namirenjem iz stečajne mase ugovornih strana ovisi o tomu koja je od ugovornih strana i u kojoj mjeri ovlaštena na raspolaganje saldom takvog računa. ${ }^{71}$ To znači kako će banka omogućiti raspolaganje saldom na takvom računu ugovornim stranama i njihovim vjerovnicima sukladno onome što je takvim poslom ugovoreno.

\section{POVREDA I NEMOGUĆNOST ISPUNJENJA OBVEZE POKROVITELJA}

Pokrovitelj može učiniti povredu obveze pomaganja na više načina. Tako, primjerice, povreda postoji kada pomaganje treće osobe u potpunosti izostane, a i kada je takva pomoć pružena, ali ono što je pruženo nije dostatno za uredno ispunjenje osigurane obveze treće osobe. Povreda postoji i kada pomoć nije pružena pravodobno radi urednog ispunjenja osigurane obveze po njezinu dospijeću (tzv. zakašnjenje pokrovitelja). ${ }^{72}$

68 Tako vidi Miladin, P., op. cit. u. bilj. 68., str. 163-164.

69 Tako vidi Miladin, P., op. cit. u. bilj. 68., str. 163-164.

70 Više o općenito escrow računu i njegovim svojstvima vidi Vukmir, B., Escrow račun (Escrow Account), Pravo i porezi, (2003) br. 3, str. 16-17.

$71 \mathrm{U}$ tom smjeru vidi Vukmir, B., Escrow račun kao instrument osiguranja plaćanja (Escrow Accounts), HGK - 16. forum poslovanja nekretninama, str. 61-62.

72 U tom smjeru vidi Horn, J., op. cit. u bilj. 1., str. 187, 189; La Corte, N., op. cit. u bilj. 9., str. 117; Kisser, J., op. cit. u bilj. 3., Rbr. 3.4.6. Sa stajališta općih pravila obveznog prava i odredbe čl. 262. ZOO78, koja sadržajno odgovara odredbi čl. 342. ZOO-a o povredi obveze i zakašnjenju, vidi Blagojević, B. T., Krulj, V., Komentar Zakona o obligacionim odnosima I., 2. 
Ne ispuni li pokrovitelj obvezu pomaganja, redovito dolazi do povrede ugovorne obveze s naslova odredbe članka 342. stavka 2. ZOO-a. Ako je pomoć pružena, ali ona nije dostatna za uredno ispunjenje osigurane obveze (npr. jer je treća osoba i dalje nesposobna za plaćanje), smatra se kako pokrovitelj također nije uredno ispunio svoju obvezu. Djelomično ispunjenje obveze pomaganja nije moguće jer se obveza pokrovitelja sastoji u pomaganju treće osobe radi njezina urednog (i potpunog) ispunjenja osigurane obveze. Nema li urednog ispunjenja osigurane obveze od strane treće osobe, nema ni urednog ispunjenja pokroviteljeve obveze pomaganja. Drugim riječima, ako treća osoba, unatoč pokroviteljevoj pomoći, ne ispuni osiguranu obvezu ili je ispuni samo djelomično, ne može se govoriti ni o ispunjenju pokroviteljeve obveze pomaganja. Pokrovitelj tada ostaje i dalje obvezan pomoći trećoj osobi, neovisno o pomoći koju je već pružio, a sve radi ispunjenja osigurane obveze. To znači kako pokrovitelj može ispuniti osiguranu obvezu i izravno primatelju izjave. ${ }^{73}$ Moguće su, međutim, situacije kod kojih ipak neće doći do povrede obveze pomaganja. Pokrovitelj odgovara samo za sposobnost ispunjenja osigurane obveze od strane treće osobe, no ne i za postojanje volje (spremnosti) treće osobe za ispunjenje te obveze. ${ }^{74}$ To znači kako nema povrede obveze pomaganja kada je treća osoba sama sposobna uredno ispuniti osiguranu obvezu, ali to jednostavno ne čini (namjerno ili nenamjerno). ${ }^{75}$ Tada primatelj izjave može prisilnim putem (ovrhom) namiriti osigurano potraživanje izravno od treće osobe kao glavnog dužnika. Pokrovitelj bi, međutim, mogao preuzeti odgovornost i za takvo neispunjenje obveze od treće osobe.

Za utvrđenje je li pokrovitelj, sukladno odredbi članka 342. stavka 2. ZOO-a, došao u zakašnjenje s ispunjenjem obveze pomaganja, potrebno je utvrditi trenutak dospijeća te obveze. Obveza redovito dospijeva u vrijeme koje je određeno ugovorom, zakonom ili temeljem drugih okolnosti posla. ${ }^{76}$ Dužnik stoga pada u zakašnjenje kada ne ispuni obvezu u roku određenom za ispunjenje, a ako takav rok nije određen, onda kada ga vjerovnik pozove na ispunjenje obveze. ${ }^{77}$ Pokroviteljske izjave u pravilu ne sadrže izričitu naznaku roka za ispunjenje obveze pokrovitelja, već samo općenito određuju kako će pokrovitelj voditi brigu o tomu da je treća osoba „svakodobno“ sposobna uredno ispuniti svoje obveze iz određenog posla. To znači kako je pokrovitelj tijekom cijelog trajanja ugovornog odnosa treće osobe i primatelja izjave dužan pomagati treću osobu kako bi ona bila u stanju po dospijeću uredno ispuniti osiguranu obvezu. Radi se stoga o trajnoj obvezi pokrovitelja. ${ }^{78} \mathrm{Iz}$

izd., 1983., Novi Sad, str. 911.

73 Tako vidi Koch, J., op. cit. u bilj. 3., str. 269-270.

74 Više o tome vidi „2. Pravna narav ugovora i predmeta obveze pokrovitelja“.

75 Takva situacija postoji kada treća osoba zbog nekog političkog rizika nije u stanju uredno ispuniti osiguranu obvezu (npr. zbog ograničenja deviznog platnog prometa). U tom smjeru vidi Horn, J., op. cit. u bilj. 1., str. 197.

76 Tako vidi odredbu čl. 173. ZOO-a, a za novčane obveze vidi odredbe Zakona o financijskom poslovanju i predstečajnoj nagodbi (NN, br. 108/12, 144/12, 81/13, 112/13, 71/15 i 78/15, dalje: ZFPPN) o ispunjenju novčanih obveza.

77 Tako vidi odredbu čl. 183. st. 1. ZOO-a kada je određen rok za ispunjenje i odredbu čl. 183. st. 2. ZOO-a kada rok za ispunjenje nije određen.

78 Tako vidi Horn, J., op. cit. u bilj. 1., str. 187-188; Schnellecke, C., op. cit. u bilj. 1., str. 30; La Corte, N., op. cit. u bilj. 9., str. 130. 
usmjerenosti pokroviteljskih izjava na postizanje određenog rezultata proizlazi kako je ispunjenje obveze pomaganja redovito vezano uz uredno ispunjenje osigurane obveze, što uključuje i vezivanje roka za ispunjenje obveze pokrovitelja rokom za ispunjenje osigurane obveze. ${ }^{79}$ To znači kako obveza pomaganja dospijeva najkasnije trenutkom dospijeća osigurane obveze, odnosno kada je treća osoba dužna uredno ispuniti osiguranu obvezu primatelju izjave, a to imovinski nije sposobna učiniti. ${ }^{80} \mathrm{~S}$ obzorom na trajnu narav pokroviteljeve obveze ne znači kako se pomoć trećoj osobi ne može pružiti i prije toga, štoviše, narav nekih oblika pomaganja nalaže pružanje takve pomoći i prije dospijeća osigurane obveze (npr. davanje potrebnih materijalnih sredstava za proizvodnju robe, čija je predaja primatelju izjave predmet osigurane obveze). S druge strane, po dospijeću osigurane obveze pomaganje se redovito svodi na izravan prijenos likvidnih sredstava radi urednog ispunjenja osigurane obveze (npr. kada je predmet osigurane obveze novčana obveza, ali i kada to nije, a novčana sredstva omogućuju trećoj osobi nabavku robe ili pružanje usluge koja je predmet osigurane obveze). Položaj pokrovitelja pritom je lakši ako je dospijeće osigurane obveze kalendarski određeno jer mu je tada poznat trenutak dospijeća osigurane obveze. Prema tomu, pokrovitelj redovito dolazi u zakašnjenje s ispunjenjem obveze pomaganja kada u zakašnjenje s ispunjenjem osigurane obveze zapadne treća osoba. ${ }^{81}$ U slučaju pokroviteljeva zakašnjenja s ispunjenjem obveze pomaganja ne primjenjuje se stoga odredba članka 183. stavka 2. ZOO-a o potrebi prethodnog pozivanja dužnika na ispunjenje obveze.

Prema odredbi članka 342. stavka 2. ZOO-a kada dužnik ne ispuni obvezu ili zakasni s njezinim ispunjenjem, vjerovnik može zahtijevati naknadu štetu koju je zbog toga pretrpio. Visina štete koja nastane primatelju izjave zbog povrede obveze pokrovitelja određuje se prema odredbi članka 346. ZOO-a o opsegu ugovorne odgovornosti za štetu. ${ }^{82}$ Visinom odštete teži se materijalnom dovođenju primatelja izjave u situaciju u kojoj bi bio po urednom ispunjenju osigurane obveze..$^{83} \mathrm{Na}$ takav odštetni zahtjev ne mogu se primijeniti pravila o naknađivanju zatezne kamate jer povrijeđena obveza pomaganja nije novčana obveza. ${ }^{84}$ Visina štete temelji se na pretpostavkama s naslova odredbe članka 346. ZOO-a, npr. visina štete ovisi o vrsti

79 Tako vidi Koch, J., op. cit. u bilj. 3., str. 272; Horn, J., op. cit. u bilj. 1., str. 189; La Corte, N., op. cit. u bilj. 9., str. 132; Bollenberger, R., Kellner, M., op. cit. u bilj. 1., Rbr. 4/44.

80 Tako vidi Horn, J., op. cit. u bilj. 1., str. 188; Schnellecke, C., op. cit. u bilj. 1., str. 30; La Corte, N., op. cit. u bilj. 9., str. 132; Kisser, J., op. cit. u bilj. 3., Rbr. 3.4.6.

81 Takvo zakašnjenje, naravno, ne nastupa ako je treća osoba imovinski sposobna uredno ispuniti osiguranu obvezu. Više o sadržaju i opsegu odštetnog zahtjeva vidi u nastavku teksta.

82 Ako je namjera ugovornih strana bilo izdavanje izjave koja je bliža garanciji, tada pokrovitelj za povrede obveze pomaganja odgovara bez obzira na krivnju. Tako vidi Kisser, J., op. cit. u bilj. 3., Rbr. 3.4.6.

83 Odštetni zahtjev primatelja izjave zbog povrede obveze pokrovitelja redovito odgovora odštetnom zahtjevu primatelja izjave zbog povrede osigurane obveze od strane treće osobe. Visina štete tako će, primjerice, odgovarati vrijednosti isplaćene glavnice zajma odnosno kredita, naknađivanju obične štete i izmakle koristi koja odgovara visini izgubljene ugovorne kamate i plaćanju zatezne kamate od dana podizanja tužbenog zahtjeva. U tom smjeru vidi Horn, J., op. cit. u bilj. 1., str. 186, 190.

84 Više o tome vidi „3. Sadržaj predmeta obveze“. 
nastale štete, ali i stupnju krivnje dužnika. ${ }^{85} \mathrm{U}$ slučaju zakašnjenja s ispunjenjem dijela ukupno osigurane obveze, npr. neplaćanja jedne ili više dospjelih rata zajma ili kredita, odštetni zahtjev prema pokrovitelju obuhvaća nastalu štetu u pogledu izostalog dijela osigurane obveze (dospjelih, a neisplaćenih rata zajma ili kredita), a ne i cjelokupnoga preostalog dijela osigurane obveze (svih preostalih nedospjelih rata) ${ }^{86}$

U slučaju raskida ugovora prije dospijeća osigurane obveze, treća osoba više ne može ispuniti osiguranu obvezu pa stoga ni pokrovitelj ne može više ispuniti obvezu pomaganja treće osobe radi urednog ispunjenja te obveze. ${ }^{87}$ To, međutim, ne znači kako zbog toga pokroviteljeva obveza prestaje s naslova odredbe članka 208. stavka 1. ZOO-a o nemogućnosti ispunjenja obveze. Takvo je stajalište nespojivo $\mathrm{s}$ interesom primatelja, a i osiguravajućom funkcijom pokroviteljske izjave. Iako obvezu pomaganja radi ispunjenja osigurane obveze tada više nije moguće ispuniti, ona se preoblikuje u pomaganje trećega u cilju urednog naknađivanja svih pravnih posljedica raskida ugovora. Prema odredbi članka 368. ZOO-a po raskidu ugovora strane ostaju obvezne naknaditi štetu jedna drugoj, vratiti ono što je jedna ugovorna strana dala drugoj u ispunjenju tog ugovora, naknaditi koristi koje su ugovorne strane imale od onoga što su dužne vratiti drugoj strani i platiti zatezne kamate. Takvo stajalište odgovarajuće čuva interese primatelja izjave jer se u slučaju raskida obveza pokrovitelja ne svodi samo na naknađivanje štete. Kada bi se obveza pomaganja svela samo na naknađivanje štete, pokroviteljske izjave izgubile bi na važnosti kada bi u slučaju raskida, a nepostojanja štete (npr. u slučaju opravdanog raskida od strane treće osobe), primatelj ostao uskraćen za naknađivanje ostalih posljedica raskida

$85 \mathrm{U}$ tom smjeru sa stajališta njemačke pravne književnosti vidi Koch, J., op. cit. u bilj. 3., str. 280-281. U slučaju povrede obveze pomaganja, zatezna kamata može biti ugrađena u odštetni zahtjev primatelja izjave prema pokrovitelju.

86 U tom smjeru sa stajališta njemačke pravne književnosti vidi Koch, J., op. cit. u bilj. 3., str. 286; Schnellecke, C., op. cit. u bilj. 1., str. 47. Pritom valja naglasiti kako se u njemačkoj pravnoj književnosti podrobno raspravlja i o mogućnosti ostvarenja odštetnog zahtjeva u slučaju povrede obveze pomaganja i s naslova odredbe $\$ 280$. st. 3. BGB-a i odredbe $\$ 281$. BGB-a o naknadi štete umjesto ispunjenja. Kako bi mogao postaviti odštetni zahtjev zbog neurednog ispunjenja, vjerovnik prvo mora ostaviti dužniku naknadni razumni rok za ispunjenje dugovane obveze, a s obzirom na okolnosti i ispuniti dodatne pretpostavke određene zakonom (npr. kada se radi o povredi dužnosti prema odredbi §241. st. 2. BGB-a). Tek po neuspješnom proteku tog roka, pravo na ispunjenje zamjenjuje se pravom na postavljanje odštetnog zahtjeva prema dužniku. Više o tome vidi Dauner-Lieb, B. u: Dauner-Lieb, B., Langen, W., BGB Schuldrecht, Band 2, 3. Aufl., 2016., Baden-Baden, BGB §280. Rbr. 43, BGB §281. Rbr. 2-3; Horn, J., op. cit. u bilj. 1. , str. 190-191, 193; Schnellecke, C., op. cit. u bilj. 1., str. 51-53. U tom pogledu hrvatsko obvezno pravo počiva na drukčijim osnovama ugovornog odštetnog prava. Pravo na naknadu štete zbog povrede ugovora uređeno je odredbama čl. 342. do 349. ZOO-a. Tim odredbama obuhvaćene su sve situacije neispunjenja, neurednog neispunjenja i zakašnjenja $\mathrm{s}$ ispunjenjem obveze, uključujući i naknadu štete u slučaju raskida ugovora s naslova odredbe čl. 360. ZOO-a. Tako vidi Perović, S., Stojanović, D., Komentar Zakona o obligacionim odnosima, 1. knjiga, 1980., Novi Sad, str. 411-412, 425, 758-759; Momčinović, H., Ugovorna odgovornost za štetu, u: Baretić, M., Brežanski, J., Buljan, V., Ćurković, M., Hrvoj-Šipek, Z., Klarić, P., Momčinović, H., Nikšić, S., Odgovornost za štetu i osiguranje od odgovornosti za štetu, 2011., Zagreb, str. 32-38.

87 Tako vidi odredbu čl. 368. st. 1. ZOO-a prema kojoj se raskidom ugovora obje ugovorne strane oslobađaju svojih obveza. 
ugovora (npr. naknađivanja koristi, plaćanja zateznih kamata i vraćanja onoga što je primljeno s naslova raskinutog ugovora) ${ }^{88} \mathrm{Ne}$ pomogne li pokrovitelj treću osobu radi urednog naknađivanja pravnih učinaka takvog raskida, primatelj izjave može prema pokrovitelju postaviti zahtjev za naknađivanje štete koja mu je zbog toga nastala. ${ }^{89}$ Imajući u vidu autonomiju volje ugovornih strana, obveza pokrovitelja može se ograničiti samo na pomaganje u ispunjenju osigurane obveze, a ne i na naknađivanje posljedica raskida ugovora. ${ }^{90}$

U ostalim slučajevima nemogućnosti ispunjenja obveze pomaganja valja primijeniti opća pravila obveznog prava. Tako je odredbom člankom 208. stavkom 1. ZOO-a određeno kako obveza prestaje kad njezino ispunjenje postane nemoguće zbog okolnosti zbog kojih dužnik (pokrovitelj) ne odgovara. Ako nemogućnost ispunjenja nastupi nakon dužnikova pada u zakašnjenje s ispunjenjem obveze, dužnik odgovara vjerovniku za štetu bez obzira na tako nastalu nemogućnost ispunjenja obveze. ${ }^{91}$ Obveza pritom prestaje ako je nemogućnost ispunjenja nastupila bez krivnje dužnika i ako se takva nemogućnost nije mogla spriječiti, izbjeći ili otkloniti, a koja je nastala u razdoblju od nastanka obveze do njezina dospijeća. Nije važno radi li se privremenoj nemogućnosti ispunjenja cijele ili dijela obveze ako zbog nje vjerovnik više ne bi imao interes za ispunjenjem takve obveze po prestanku privremene nemogućnosti. ${ }^{92}$

Ako pokrovitelj ne može pružiti pomoć trećoj osobi zbog njemu svojstvenih okolnosti, to redovito neće biti dovoljno za oslobođenje od obveze pomaganja treće osobe. ${ }^{93}$ Izostanak potrebnih sredstava za ispunjenje obveze pomaganja (npr. zbog prezaduženosti ili nesposobnosti za plaćanje) ne dovodi do prestanka i isključenja

88 Tako vidi Koch, J., op. cit. u bilj. 3., str. 291-292.

89 U tom smjeru vidi Koch, J., op. cit. u bilj. 3., str. 292.

90 U ovom pogledu nameće se pitanje zlouporabe utjecaja pokrovitelja radi izazivanja raskida ugovora između primatelja izjave i treće osobe, a sve radi njegova izbjegavanja ispunjenja obveze pomaganja. Takvo postupanje protivno je načelima obveznog prava (npr. načelu savjesnosti i poštenja i zabrani prouzročenja štete) što, primjerice, može dovesti do odštetne odgovornosti pokrovitelja, a i promjene činjeničnog stanja (npr. vidi odredbu čl. 297. st. 4. ZOO-a o uvjetima i njihovom učinku). Tako u pogledu načela savjesnosti i poštenja vidi Osrečak, J., Poredbenopravni prikaz načela savjesnosti i poštenja, Zagrebačka pravna revija, sv. 3, br. 1 (2014), str. 58.

91 Tako vidi odredbu čl. 342. st. 4. ZOO-a. Pored navedenih općih pravila o nemogućnosti ispunjenja zakonodavac poznaje i posebne situacije nemogućnosti ispunjenja za koje ne odgovara niti jedna ugovorna strana (čl. 343. ZOO i čl. 373. ZOO) i situacije nemogućnosti ispunjenja za koje odgovara druga strana (čl. 374. ZOO).

92 Tako vidi Blagojević, B. T., Krulj, V., op. cit. u bilj. 72., str. 1109; Perović, S., Stojanović, D., op. cit. u bilj. 86., str. 896; Gorenc, V., Belanić, L., Momčinović, H., Perkušić, A., Pešutić, A., Slakoper, Z., Vukelić, M., Vukmir, B., Komentar Zakona o obveznim odnosima, 2. izd., 2014., Zagreb, str. 313-314.

93 Tako, primjerice, bolest ili pokroviteljevo lišenje slobode. U tom smjeru vidi Koch, J., op. cit. u bilj. 3., str. 275. Eventualno oslobođenje od odgovornosti može nastupiti u slučaju nemogućnosti ispunjenja za koju ne odgovara dužnik prema odredbi čl. 208. st. 1. ZOO-a i prema odredbi čl. 343. ZOO-a. Pritom valja paziti na ograničenja iznesenog pravila sadržana u odredbama čl. 209. i čl. 342. st. 4. ZOO-a. Moguće oslobođenje od odgovornosti tako bi moglo, primjerice, nastupiti u slučaju izvanredne i nepredvidive zabrane prijenosa deviznih sredstava pokrovitelja u inozemstvo s ciljem pružanja pomoći trećoj osobi od strane javne vlasti države sjedišta pokrovitelja. Tako vidi Koch, J., op. cit. u bilj. 3., str. 276. 
pokroviteljeve odgovornosti za neispunjenje te obveze. ${ }^{94}$ Takvo stajalište podupire $i$ to što pokrovitelj redovito ima široke diskrecijske ovlasti u pogledu načina ispunjenja obveze pomaganja. Jednako tako ni početna nemogućnost ispunjenja koja postoji u trenutku nastanka obveze ne utječe na obvezu pomaganja. ${ }^{95}$ Odštetna odgovornost pokrovitelja može se, međutim, isključiti ili smanjiti zbog nastupanja promijenjenih okolnosti. ${ }^{96}$

Do nemogućnosti ispunjenja obveze pomaganja ne dovodi ni odbijanje suradnje treće osobe. ${ }^{97}$ Takvo odbijanje suradnje postoji kod pasivnog držanja treće osobe prema pokrovitelju i njegovoj ponudi za pružanje pomoći, kod odbijanja primitka ponuđene pomoći pokrovitelja, ali i odbijanja davanja pravovremenih informacija pokrovitelju o nesposobnosti urednog ispunjenja osigurane obveze. Takvu je situaciju teško zamisliti kada su pokrovitelj i treća osoba sudionici istog koncerna kod kojeg vladajuće društvo može korištenjem svojeg utjecaja naložiti trećoj osobi suradnju radi urednog ispunjenja osigurane obveze. ${ }^{98}$ C̆ak i kada nema koncerna temeljem kojeg bi se trećoj osobi mogla nametnuti dužnost suradnje, izostanak suradnje ne dovodi do nemogućnosti ispunjenja obveze pomaganja. Osim rizika nemogućnosti utjecaja na treću osobu, pokrovitelj snosi i rizik nemogućnosti pribavljanja informacija bitnih za ispunjenje obveze pomaganja. U suprotnom bi obveza pomaganja bila uvjetovana mogućnošću korištenja utjecaja usmjerenog na uredno ispunjenje osigurane obveze od strane treće osobe i mogućnošću dobivanja potrebnih informacija od treće osobe. Time se jača osiguravajuća funkcija pokroviteljskih izjava. ${ }^{99}$ Takvi se rizici nadomještaju diskrecijom pokrovitelja glede izbora načina ispunjenja obveze pomaganja kao i njegovom mogućnošću ispunjenja osigurane obveze izravno primatelju izjave. ${ }^{100} \mathrm{~S}$ tim rizicima usko je vezan i rizik potrebe dodatnog pomaganja treće osobe kojeg, također, snosi pokrovitelj. ${ }^{101}$

S tim u vezi, nameće se i pitanje je li pokrovitelj tijekom trajanja obveze pomaganja treće osobe dužan zadržati ili steći mogućnost utjecaja na treću osobu radi nadzora nad ispunjenjem osigurane obveze i davanja obvezujućih uputa usmjerenih na takvo ispunjenje (npr. sudjelovanjem u zajedničkom koncernu ili stjecanjem

94 Tako vidi Koch, J., op. cit. u bilj. 3., str. 263-264.

95 Tako vidi odredbu čl. 208. st. 1. ZOO-a. Tada je potrebno postojanje apsolutne nemogućnosti ispunjenja pod koju se ne može podvesti nemogućnost ispunjenja zbog toga što pokrovitelj osobno nema sredstva za ispunjenje obveze pomaganja treće osobe. Tako vidi Blagojević, B. T., Krulj, V., op. cit. u bilj. 72., str. 1109; Gorenc, V., Belanić, L., Momčinović, H., Perkušić, A., Pešutić, A., Slakoper, Z., Vukelić, M., Vukmir, B., op. cit. u bilj. 92., str. 413.

96 Pravni učinci promijenjenih okolnosti svode se na raskid ugovora te posljedično naknađivanje pravičnog dijela štete odnosno na izmjenu ugovora koji potpada pod režim promijenjenih okolnosti sukladno mjerodavnoj odredbi ZOO.

97 Tako vidi Koch, J., op. cit. u bilj. 3., str. 264.

98 Tako, primjerice, vidi odredbu čl. 496. ZTD-a o granicama utjecaja u faktičnom koncernu kada nema ugovora o vođenju poslova društva.

99 Tako vidi Koch, J., op. cit. u bilj. 3., str. 276-277.

100 Više o tome vidi „3. Sadržaj predmeta obveze“ i „4. Pravo pokrovitelja na ispunjenje osigurane obveze izravno primatelju izjave".

101 Više o tome vidi „4. Pravo pokrovitelja na ispunjenje osigurane obveze izravno primatelju izjave“. 
članskih udjela u društvu treće osobe)? ${ }^{102} \mathrm{U}$ tom pogledu ponajprije valja naglasiti kako takvo stjecanje ili naknadni gubitak utjecaja nad trećom osobom nije odlučan za ispunjenje preuzete obveze pomaganja. Iako su pokrovitelj i treća osoba redovito sudionici istog koncerna, postojanje koncerna ili drugog oblika povezanosti nije preduvjet za ispunjenje obveze pomaganja treće osobe pa se tako, primjerice, prijenos novčanih sredstava s računa pokrovitelja na račun treće osobe, a radi njezina urednog ispunjenja osigurane obveze, može učiniti neovisno o tomu jesu li pokrovitelj i treća osoba sudionici istog koncerna. S druge strane, kako instrumenti koncerna omogućuju pokrovitelju nadzor nad načinom korištenja pružene pomoći, ali i ostvarivanje utjecaja na način koji će dovesti do urednog ispunjenja osigurane obveze, koncern pokrovitelju može ukloniti rizik izostanka suradnje i zlouporabe dobivene pomoći od treće osobe. ${ }^{103} \mathrm{U}$ slučaju nepostojanja tih instrumenata, pokrovitelj uvijek može pokušati interno dogovoriti s trećom osobom posebne mehanizme kontrole i nadzora, a i sankcije u slučaju zlouporabe dobivene pomoći. ${ }^{104}$ Stoga je isključivo na pokrovitelju hoće li, radi smanjenja ili čak uklanjanja navedenih rizika, ići za time da stjecanjem utjecaja nad trećom osobom dobije potrebne mehanizme nadzora i kontrole ispunjenja osigurane obveze. ${ }^{105}$

\section{STEČAJNI POSTUPAK, ZAJAM KOJIM SE NADOMJEŠTA TEMELJNI KAPITAL I POSTUPAK IZVANREDNE UPRAVE}

Otvaranje stečajnog postupka na trećom osobom ne dovodi do prestanka pokroviteljeve obveze (npr. s naslova odredbe čl. 208. st. 1. ZOO-a o nemogućnosti ispunjenja). Kako otvaranje tog postupka ne dovodi do prestanka pravne osobnosti treće osobe, a tako ni prestanka njezinih obveza, pokrovitelj i dalje može pomoći treću osobu radi njezina urednog ispunjenja osigurane obveze. ${ }^{106}$

102 Mogućnost ostvarenja takvog utjecaja može se, primjerice, postići stjecanjem članskih udjela u društvu kćeri, ali i sklapanjem poduzetničkog ugovora (npr. ugovora o vođenju poslova) pokrovitelja i društva treće osobe. To pravno pitanje nameće i mnogobrojna sporedna pitanja, kao što je utvrđivanje pravnih posljedica u slučaju povrede takve dužnosti kao i njezine naravi (npr. je li postojanje takvog utjecaja uvjet ugovora). U pogledu problematike postavljenog pitanja sa stajališta njemačke pravne književnosti vidi Koch, J., op. cit. u bilj. 3., str. 293.

103 Tako vidi Koch, J., op. cit. u bilj. 3., str. 294. Više o korištenju bankovnog računa sa zaporkom i escrow računa vidi „4. Pravo pokrovitelja na ispunjenje osigurane obveze izravno primatelju izjave“".

104 Tako, primjerice, može ugovoriti dužnosti obavještavanja (jednokratnih, povremenih) o okolnostima važnim za pokroviteljevo ispunjenje obveze pomaganja, a u slučaju njezine povrede odnosno zlouporabe dobivene pomoći mogu ugovoriti ugovornu kaznu. Ugovaranje takvih odredaba može se nametnuti kao jedan od uvjeta budućega poslovnog aranžmana pokrovitelja i treće osobe u stadiju kada pokrovitelj još nije preuzeo obvezu pomaganja treće osobe prema primatelju izjave.

105 Tako vidi Koch, J., op. cit. u bilj. 3., str. 295-296.

106 Stečajni dužnik prestaje postojati tek brisanjem iz sudskog registra koje nastupa dostavom rješenja o zaključenju stečajnog postupka sukladno odredbi čl. 286. st. 3. SZ-a. U tom smjeru sa stajališta njemačke pravne književnosti vidi Koch, J., op. cit. u bilj. 3., str. 298-299; La Corte, N., op. cit. u bilj. 9, str. 138, 241, 244. 
Prema odredbi članka 134. stavka 1. SZ-a stečajna masa obuhvaća cjelokupnu imovinu dužnika u vrijeme otvaranja stečajnog postupka, ali i imovinu koju dužnik stekne tijekom stečajnog postupka. To znači kako dobivena sredstva pomoći ulaze u stečajnu masu treće osobe, a koja ne služi isključivo namirenju osiguranog potraživanja primatelja izjave, već i namirenju potraživanja svih ostalih stečajnih vjerovnika. ${ }^{107}$ Pružena pomoć koja odgovara vrijednosti osigurane obveze redovito neće biti dovoljna za uredno ispunjenje te obveze jer njezinom diobom na stečajne vjerovnike redovito ne preostaje dovoljno sredstava za potpuno namirenje osiguranog potraživanja (npr. kada vrijednost pružene pomoći odgovara vrijednosti osigurane obveze, a ukupna potraživanja stečajnih vjerovnika premašuju iznos pružene pomoći). Ako osigurana obveza stoga ostane nenamirena, smatra se kako ni pokrovitelj nije uredno ispunio obvezu pomaganja. Primatelj izjave može tada tražiti novo pomaganje treće osobe radi potpunog namirenja osigurane obveze. Takvo pomaganje likvidnošću, koje služi namirenju i ostalih stečajnih vjerovnika, redovito nije u ekonomskom interesu pokrovitelja. ${ }^{108}$ Pokrovitelj se stoga radije odlučuje na ispunjenje osigurane obveze izravno primatelju izjave jer time izbjegava pružanje pomoći koja svojom vrijednošću redovito prelazi vrijednost osigurane obveze.

Ako je stečajni postupak pokrenut nad trećom osobom i nad pokroviteljem, primatelj izjave može isticati u oba postupka svoje potraživanje s naslova osiguranog posla i potraživanje s naslova pokroviteljske izjave uz odgovarajuću primjenu odredbe članka 142. SZ-a. ${ }^{109}$ Isticanje potraživanja s naslova pokroviteljske izjave tada je, unatoč ograničenoj akcesornosti obveze pomaganja prema osiguranoj obvezi, ograničeno visinom osiguranog potraživanja u trenutku otvaranja stečajnog postupka nad trećom osobom. S druge strane, to znači kako u slučaju otvaranja stečajnog postupka isključivo nad osobom pokrovitelja nije moguće primijeniti odredbu članka 140. stavka 1. SZ-a o dospijeću nedospjelih potraživanja stečajnih vjerovnika. To je stoga što u trenutku otvaranja tog postupka još nije izvjesno postoji li uopće potreba pomaganja treće osobe radi njezina urednog ispunjenja osigurane obveze jer

107 Tako vidi Schnellecke, C., op. cit. u bilj. 1., str. 48.

108 Takvo što bilo bi u interesu pokrovitelja kada bi pokrovitelj temeljem stečajnog plana u postupak restrukturiranja htio preuzeti udjele u društvu stečajnog dužnika ili kada bi posljedica povrede obveze pomaganja svojim vrijednosnim opsegom prelazila vrijednost takve pomoći (npr. s naslova ugovorne kazne i odgovornosti za štetu). U tom smjeru vidi Koch, J., op. cit. u bilj. 3., str. 300.

109 Predmetna odredba SZ-a određuje kako vjerovnik kojem više osoba odgovara za ispunjenje iste činidbe u cijelosti, može u stečajnom postupku, protiv svakog od dužnika, isticati do svog potpunog namirenja cijeli iznos koji je zahtijevao u vrijeme otvaranja stečajnog postupka. Iako se obveza pokrovitelja i osigurana obveza treće osobe ne mogu kategorizirati kao solidarne obveze ili druge obveze obuhvaćene širim pojmom ,ista činidba“ (npr. jamčeva obveza i obveza glavnog dužnika), radi ostvarenja što potpunijeg namirenja primatelja izjave (vjerovnika) predmetnu odredbu valja odgovarajuće primijeniti i na potraživanja s naslova pokroviteljskih izjava. U tom smjeru sa stajališta odredbe $§ 43$ InsO-a koja sadržajno odgovara predmetnoj odredbi čl. 142. SZ-a vidi Bäuerle, E., u: Braun, E., Insolvenzordnung (InsO), Kommentar, 7. Aufl., 2017., München, InsO § 43 Rbr. 1; Thonfeld, H., u: Schmidt, K., Insolvenzordnung, Band 27, 19. Aufl., 2016., München, InsO § 43 Rbr. 1; Koch, J., op. cit. u bilj. 3., str. 194-195; Schnellecke, C., op. cit. u bilj. 1., str. 59-60. 
treća osoba može biti u stanju i sama uredno ispuniti osiguranu obvezu primatelju izjave. ${ }^{110} \mathrm{U}$ suprotnom bi primatelj izjave mogao (makar djelomično) namiriti svoje potraživanje iz stečajne mase pokrovitelja, a potom se po dospijeću osigurane obveze i uredno namiriti za osigurano potraživanje od treće osobe. U takvim situacijama na potraživanje s naslova pokroviteljske izjave, valja stoga odgovarajuće primijeniti pravila stečajnog postupka o potraživanju vezanom uz odgodni uvjet. ${ }^{111}$

Iz ustaljenog izričaja pokroviteljskih izjava proizlazi kako su takve izjave usmjerene na postizanje urednog ispunjenja osigurane obveze po njezinu dospijeću, a ne i na svakodobno očuvanje likvidnosti treće osobe odnosno sprječavanje otvaranja stečajnog postupka nad njome. ${ }^{112}$ Takav izričaj redovito sadrže i druga osobna osiguranja ispunjenja tuđe obveze (npr. jamstvo). ${ }^{113}$ Pomaganje likvidnošću radi izbjegavanja stečajnog postupka ili svakodobnog očuvanja likvidnosti treće osobe može biti određeno kao svrha pokroviteljske izjave, ali tada mora biti izričito ugovoreno i jasno izraženo u samoj izjavi. Pomaganje radi urednog ispunjenja osigurane obveze sadržajno je uže od pomaganja radi održavanja likvidnosti treće osobe jer je usmjereno na pomaganje radi ispunjenja određene (osigurane) obveze. Održavanje likvidnosti, s druge strane, nije usmjereno na ispunjenje određene obveze, već je generalne naravi zbog čega koristi svim vjerovnicima treće osobe. Otvaranje stečajnog postupka ne znači povredu ispunjenja osigurane obveze i obveze pomaganja jer je osiguranu obvezu i dalje moguće uredno ispuniti, primjerice, odgovarajućim (redovito otegotnijim i stoga u praksi rjeđim) pomaganjem treće osobe usmjerenim na uredno ispunjenje osigurane obveze (a time redovito i ispunjenje obveza drugih stečajnih vjerovnika) ili pokroviteljevim ispunjenjem osigurane obveze izravno primatelju izjave (u praski češće). Iz istih razloga ni prijenos ovlaštenja vođenja poslova s poslovodnog organa treće osobe na stečajnog upravitelja (čl. 159. SZ) ne dovodi do nemogućnosti ispunjenja obveze pomaganja treće osobe. ${ }^{114}$

Pokrovitelj ne može izjaviti raskid niti zahtijevati pravičnu izmjenu

110 U tom smjeru sa stajališta odredbe $\S 41$ InsO-a koja sadržajno odgovara predmetnoj odredbi čl. 140. SZ-a vidi Bitter, G., u: Kirchhof, H., Eidenmüller, H., Stürner, R., Münchener Kommentar zur Insolvenzordnung, Band 1, 3. Aufl., 2013., München, InsO § 41 Rbr 39, InsO § 43 Rbr. 12; Thonfeld, H., u: Schmidt, K., Insolvenzordnung, Band 27, 19. Aufl., 2016., München, InsO § 43 Rbr. 2.

111 U tom smjeru sa stajališta njemačke pravne književnosti, vidi Bitter, G., loc. cit., Thonfeld, H., loc. cit. Takvo će potraživanje primatelj izjave također prijaviti stečajnom upravitelju, ali se ona neće isplatiti dok se ne ispuni odgodni uvjet. Više o tretmanu potraživanja vezanih uz odgodni uvjet vidi, primjerice, odredbu čl. 106. st. 7. SZ-a o pravu glasa stečajnog vjerovnika, čije je potraživanje vezano za odgodni uvjeti kao i odredbu čl. 277. SZ-a o diobi potraživanja vezanog uz odgodni uvjet.

112 Tako, primjerice, ranije navedeni primjeri izričaji pokroviteljskih izjava navode kako se pokrovitelj obvezuje kako će pomagati treću osobu na način koji će joj „omogućiti uredno ispunjenje svih obveza“ primatelju izjave ili će ju dovesti u položaj da bude sposobna ,uredno ispuniti sve obveze" iz osiguranog posla.

113 Vidi odredbu čl. 104. ZOO-a prema kojoj se jamac obvezuje vjerovniku uredno ispuniti valjanu i dospjelu obvezu iz osnovnoga pravnog posla u slučaju neispunjenja te obveze od glavnog dužnika.

114 U tom smjeru sa stajališta njemačke pravne književnosti vidi Koch, J., op. cit. u bilj. 3., str. 302-304. 
pokroviteljske izjave tvrdeći kako mu je zbog otvaranja stečajnog postupka ispunjenje obveze pomaganja „pretjerano otežano" ili bi mu nanijelo „pretjerano veliki gubitak“ zbog znatno povećanih zahtjeva za likvidnošću treće osobe. Pokrovitelju valja onemogućiti postavljanje takvog zahtjeva imajući u vidu odredbu članka 369. stavka 2. ZOO-a, prema kojoj se ugovorna strana ne može pozivati na izmjenu ili raskid, ako je bila dužna u vrijeme sklapanja ugovora uzeti u obzir te okolnosti ili ih je mogla izbjeći ili savladati. Naime, zbog značajne diskrecije glede izbora vremena i načina ispunjenja obveze pomaganja, pokrovitelj se redovito nalazi u poziciji pravodobno poduzeti potrebne radnje (npr. pružiti pomoć trećoj osobi) radi izbjegavanja stečajnog postupka. Ako se stečajni postupak ipak pokrene, pokrovitelj može izbjeći negativne učinke pomaganja stečajne mase u pogledu svih stečajnih vjerovnika i izravnim ispunjenjem osigurane obveze primatelju izjave s naslova odredbe članka 161. stavka 2. ZOO-a. ${ }^{115}$

Izneseno ne znači kako je otvaranje stečajnog postupka bez važnosti za pokroviteljevu obvezu. Otvaranje tog postupka trenutak je kada je pokrovitelj najkasnije dužan poduzeti potrebne radnje radi urednog ispunjenja osigurane obveze, jer tada dospijeva osigurano potraživanje. ${ }^{116}$ To znači kako primatelj izjave može postaviti odštetni zahtjev pokrovitelju zbog povrede obveze pomaganja tek kada pokrovitelj po otvaranju stečajnog postupka bez odgađanja ne poduzme potrebne radnje koje dovode do urednog ispunjenja osigurane obveze. ${ }^{117}$ Za postavljanje takvog odštetnog zahtjeva, primatelj izjave mora prijaviti osigurano potraživanje u stečajnom postupku (čl. 257. SZ), no pritom nije dužan čekati utvrđivanje prijavljenog potraživanja prema stečajnom dužniku (čl. 263. SZ). ${ }^{118}$ Tomu u prilog govori ograničena akcesornost pokroviteljeve

115 U tom smjeru sa stajališta odredbe §275. st. 2. BGB-a o isključenju obveze ispunjenja zbog promijenjenih okolnosti vidi Koch, J., op. cit. u bilj. 3., str. 303; La Corte, N., op. cit. u bilj. 9. , str. 247-248.

116 Tako vidi odredbu čl. 140. st. 1. SZ-a prema kojoj nedospjela potraživanja dospijevaju otvaranjem stečajnog postupka. Kako se kod pokroviteljske izjave ne radi o jamstvu, nije moguće primijeniti pravilo iz odredbe čl. 113. ZOO-a o jamčevu zadržavanju prava na rok u slučaju dužnikova gubitka tog prava. U tom smjeru vidi Koch, J., op. cit. u bilj. 3., str. 301-302. To ne znači kako stečaj treće osobe ne može u konačnici rezultirati okolnostima koje će predstavljati povredu pa i nemogućnost ispunjenja obveze pomaganja. Tako će, primjerice, povreda obveze pomaganja nastupiti kada pokrovitelj po otvaranju stečajnog postupka ne poduzme potrebne radnje radi urednog ispunjenja osigurane obveze, dok nemogućnost ispunjenja te obveze svakako nastupa prestankom treće osobe, kao stečajnog dužnika, po završetku stečajnog postupka (čl. 286. st. 3. SZ). No, na takvu nemogućnost ispunjenja nije moguće primijeniti odredbu čl. 208. ZOO-a o prestanku obveze, jer je pokrovitelj do njezina nastanka (prestanka osobe stečajnog dužnika) bio u zakašnjenju s ispunjenjem obveze pomaganja. Za suprotno stajalište prema kojem već po otvaranju stečajnog postupka nad trećom osobom dolazi do povrede obveze pomaganja i mogućnosti postavljanja odštetnog zahtjeva prema pokrovitelju vidi Schnellecke, C., op. cit. u bilj. 1., str. 47. Više o općenito nemogućnosti ispunjenja vidi „5. Povreda i nemogućnost ispunjenja obveze pokrovitelja“.

117 Više o povredi obveze pokrovitelja vidi „5. Povreda i nemogućnost ispunjenja obveze pokrovitelja“.

118 Prijavu potraživanja potrebno je učiniti radi zaštite pokroviteljevih prava s naslova naknadnoga regresnog zahtjeva prema trećoj osobi u slučaju njegova izravnog ispunjenja osigurane obveze primatelju izjave. Ako to ne učini odgovara za štetu pokrovitelju koja mu zbog toga nastane (npr. 
obveze prema obvezi primatelja (akcesornost samo u pogledu postojanja osigurane obveze), održavanje osiguravajuće funkcije i očuvanje svrhovitosti takvog osiguranja u pravnom prometu. ${ }^{119}$ Visina odštetnog zahtjeva određuje se sukladno općim pravilima obveznog prava o ugovornoj odgovornosti za štetu (npr. prema odredbi čl. 346. ZOO). ${ }^{120}$

Kada su pokrovitelj i treća osoba povezana društva, što je redovito slučaj, pri postavljanju zahtjeva primatelja izjave prema trećoj osobi na ispunjenje osigurane obveze valja voditi računa o pravilima o zajmu kojim se nadomješta temeljni kapital. ${ }^{121}$ Prema odredbi članka 408. stavka 2. ZTD-a kada društvo u krizi dobije zajam od osobe izvan društva, a član tog društva dade osiguranje za povrat tog zajma, zajmodavac može u stečajnom postupku protiv društva ostvarivati zahtjev za povratom zajma samo u iznosu koji nije namiren s naslova dobivenog osiguranja. ${ }^{122}$ To znači kako je zajmodavac (primatelj izjave) u slučaju stečaja zajmoprimca (treće osobe) dužan prije namirenja potraživanja iz stečajne mase zajmoprimca s naslova osiguranog posla tražiti od člana društva (pokrovitelja) poduzimanje pravnih radnji usmjerenih na uredno ispunjenje osigurane obveze (obveze pomaganja). ${ }^{123}$ Imajući u vidu kako otvaranjem

u iznosu vrijednosti koja mu diobom stečajne mase pripadne). Za drukčije stajalište njemačke pravne književnosti koje se djelomično temelji na analognoj primjeni pravila o jamstvu za slučaj nemogućnosti namirenja osiguranog potraživanja vidi Koch, J., op. cit. u bilj. 3., str. 304305.

119 Ako prijavljeno potraživanje bude osporeno, pokrovitelj može protiv zahtjeva primatelja izjave istaknuti prigovor nepostojanja osiguranog potraživanja, a ako je ispunio osiguranu obvezu izravno primatelju izjave može od njega tražiti povrat ispunjenog s naslova stjecanja bez osnova. Ako se umjesto izravnog ispunjenja osigurane obveze pokrovitelj odluči za otegotnije pomaganje treće, u slučaju osporenog osiguranog potraživanja, pokrovitelj također može od treće osobe tražiti vraćanje s naslova stjecanja bez osnove.

120 Takav odštetni zahtjev u pravilu obuhvaća svu štetu koja nastane primatelju izjave zbog neispunjenja osigurane obveze što uključuje i izmaklu korist. U tom smjeru vidi La Corte, N., op. cit. u bilj. 9., str. 249.

121 Povezanost takvih društva ograničena je na slučajeve kapitalne povezanosti, odnosno na situacije kada jedno društvo u drugom društvu ima većinski udio, zatim kada se radi o ovisnom i vladajućem društvu temeljem članstva jednog društva u drugome društvu te kada se radi o društvima s uzajamnim udjelima (usporedi s odredbom čl. 473. ZTD o povezanim društvima).

122 Iznesena pravila o zajmu kojim se nadomješta temeljni kapital primjenjuju se na društva $\mathrm{s}$ ograničenom odgovornošću. No, pritom valja upozoriti kako se prema odredbi čl. 408. st. 3. ZTD-a iznesena pravila o zajmu kojim se nadomješta temeljni kapital primjenjuju na članove društva koji vode poslove društva i/ili čiji poslovni udio otpada na više od deset posto temeljnoga kapitala društva. Više o tome vidi Barbić, J., op. cit. u bilj. 46., str. 310-316. Pravila o zajmu kojim se nadomješta temeljni kapital primjenjuju se uz ograničenja i na dionička društva. Tako odredbom čl. 217. st. 3. ZTD-a predmetna pravila valja na odgovarajući način primijeniti na slučajeve kada je zajam dao dioničar čije se dionice odnose na najmanje četvrtinu temeljnoga kapitala društva, a društvo bez tog zajma u svom poslovanju ne bi moglo iskazati dobit. Više o tome vidi Barbić, J., op. cit. u bilj. 46., str. 347. Za odgovarajuća rješenja njemačkog prava vidi Schnellecke, C., op. cit. u bilj. 1., str. 58.

123 Prema odredbi čl. 408. st. 3. ZTD-a pravilima o zajmu, kojim se nadomješta temeljni kapital, nije obuhvaćen samo zajam, njome su obuhvaćene i druge radnje koje u gospodarskom smislu odgovaraju davanju zajma, kao što je, primjerice, ugovori o kreditu i podmirenje vjerovnika društva uz odgodu regresa prema društvu. Više o tome vidi Barbić, J., op. cit. u bilj. 46, str. 312. Za potvrdu kako su odredbom čl. 408. st. 2. ZTD-a obuhvaćene i pokroviteljske izjave (kao 
stečajnog postupka pokrovitelj pada u zakašnjenje ako bez odgađanja ne poduzme takve radnje, primatelj izjave redovito neće niti tražiti od pokrovitelja poduzimanje tih radnji, već će se obratiti izravno pokrovitelju s odštetnim zahtjevom zbog povrede preuzete obveze pomaganja. Na takav odštetni zahtjev također treba primijeniti predmetnu odredbu što znači kako se primatelj izjave, prije postavljanja zahtjeva za povratom osiguranog zajma iz stečajne mase treće osobe, mora s odgovarajućim odštetnim zahtjevom ponajprije obratiti pokrovitelju. ${ }^{124} \mathrm{U}$ slučaju ispunjenja zahtjeva primatelja izjave, ograničava se pravo pokrovitelja na ostvarivanje regresnog zahtjeva prema trećoj osobi sukladno odredbi članka 408. stavka 1. ZTD-a. ${ }^{125}$

Konačno, valja se osvrnuti i na rješenja novog Zakona o postupku izvanredne uprave u trgovačkim društvima od sistemskog značaja za Republiku Hrvatsku (dalje: ZPIU). ${ }^{126}$ Tim se zakonom nastoji očuvati održivost poslovanja trgovačkih društava koja svojim opsegom poslovanja i položajem na tržištu, a u slučaju postojanja nekog od razloga za otvaranje postupka predstečajne nagodbe ili stečajnog postupka, mogu ugroziti stabilnost nacionalnoga gospodarskog sustava (npr. kao što je koncern Agrokor). ${ }^{127}$ Tim se zakonom uspostavlja postupak izvanredne uprave nad krizom obuhvaćenim društvom kojim se rade pripreme za sklapanje nagodbe s vjerovnicima radi sprječavanja i kontrole nastanka štetnih posljedica za nacionalno gospodarstvo, teži postizanju što potpunijeg namirenja vjerovnika, a potencijalno i ponovnoj uspostavi likvidnosti i urednog poslovanja. Takav postupak uvelike utječe na redovite poslovodne procese u zahvaćenom društvu, ali i u društvima koja su ovisna o njemu ili su s njim povezana. ${ }^{128}$ Pored toga, kako pokroviteljske izjave redovito izda neko od povezanih društava u korist drugog društva iste grupacije (npr. izjava društva majke u korist društva kćeri i obratno), potrebno je odgovoriti na pitanje učinka takvog postupka na pokroviteljske izjave izdane od strane ili u korist društava obuhvaćenih tim postupkom. ${ }^{129}$ Pritom valja općenito razlikovati je li pokrovitelj društvo od

patronatsko očitovanje) vidi Barbić, J., op. cit. u bilj. 46., str. 311.

124 Tako vidi Koch, J., op. cit. u bilj. 3., str. 308; Schnellecke, C., op. cit. u bilj. 1., str. 58-59.

$125 \mathrm{U}$ tom smjeru sa stajališta austrijske pravne književnosti vidi Bollenberger, R., Kellner, M., op. cit. u bilj. 1., Rbr. 4/80.

126 Zakon o postupku izvanredne uprave u trgovačkim društvima od sistemskog značaja za Republiku Hrvatsku (NN, br. 32/17).

127 Više o razlozima donošenja ZPIU-a vidi Prijedlog Zakona o postupku izvanredne uprave u trgovačkim društvima od sistemskog značaja za Republiku Hrvatsku, P.Z. br. 116. (dostupno na službenoj web stranici Hrvatskog sabora). Predmetni zakon, u javnosti poznat i kao „Lex Agrokor“, nastaje u hitnom postupku kao odgovor na financijsku nestabilnost u poslovanju domaćeg koncerna Agrokor.

128 Tako, primjerice, vođenje poslova društva od sistemskog značaja preuzima izvanredni povjerenik koji ima prava i obveze poslovodnog organa tog društva te ga zastupa samostalno i pojedinačno, a u ime tog društva ostvaruje i sva prava povezana s vlasničkim udjelom tog društva u drugim povezanim i ovisnim društvima. Više o tome vidi odredbu čl. 12. ZPIU-a.

129 Tako vidi odredbu čl. 5. st. 1. ZPIU-a prema kojoj se postupak izvanredne uprave, osim na društva od sistemskog značaja (vidi čl. 4. ZPIU), primjenjuje i na društvo koje ne ispunjava uvjete za njegovu kvalifikaciju kao društvo od sistemskog značaja ako se ono smatra ovisnim društvom ili povezanim društvom, a vladajuće društvo samostalno ili zajedno s tim društvom ispunjava uvjete za kvalifikaciju društva kao društva od sistemskog značaja. Prema odredbi čl. 4. st. 2. ZPIU-a društvom od sistemskog značaja smatra se dioničkog društvo koje kumulativno: 
sistemskog rizika ili neko od povezanih ili ovisnih društava obuhvaćenih predmetnim postupkom, a potom i je li pokroviteljska izjava izdana prije ili nakon što je pokrenut taj postupak.

Poslovanjem društva od sistemskog rizika upravlja izvanredni povjerenik koji samostalno vodi poslovanje društva, poduzima sve mu povjerene radnje, a može samostalno poduzimati i sve radnje potrebne za redovito poslovanje društva (čl. 12. st. 7. ZPIU). Shodno tomu, ako je pokroviteljska izjava izdana nakon otvaranja predmetnog postupka, izvanredni povjerenik može poduzeti radnje potrebne za ispunjenje obveze pomaganja kada su one potrebne za redovito poslovanje društva. ${ }^{130}$ Širim pojmom radnji potrebnih za redovito poslovanje društva obuhvaćene su i radnje koje su nužne za redovito poslovanje sukladno ZFPPN-u. Prema tom zakonu za redovno poslovanje nužne su, između ostalog, radnje koje su predviđene kao mjere financijskog restrukturiranja društva. ${ }^{131}$ Preuzimanje obveze pomaganja s naslova pokroviteljske izjave može se smatrati mjerom financijskog restrukturiranja kada je, primjerice, takvu obvezu preuzelo društvo obuhvaćeno postupkom izvanredne uprave, a radi osiguranja nužnog zaduženja drugog društva obuhvaćenog istim postupkom.

Ako je, međutim, pokroviteljska izjava izdana prije otvaranja postupka izvanredne uprave pa potom bude potrebno ispuniti obvezu pomaganja, takvo ispunjenje provodi se sukladno odredbi članka 40. stavka 1 . ZPIU-a. ${ }^{132}$ Prema toj odredbi, izvanredni povjerenik može izvršiti plaćanje dospjelih potraživanja koja su nastala prije otvaranja postupka izvanredne uprave ako je to nužno radi smanjenja sistemskog rizika, nastavka poslovanja, očuvanja imovine i ako se radi o potraživanjima iz redovitog ili operativnog poslovanja, ali samo uz suglasnost vjerovničkog vijeća. Pritom su iz takvih potraživanja izričito izuzeta potraživanja financijskih i kreditnih institucija i imatelja vrijednosnih papira, osim ako se radi

1) ima prosječno više od pet tisuća zaposlenih u godini koja prethodi godini u kojoj je podnesen prijedlog za otvaranje postupka izvanredne uprave te 2) društvo kod kojeg obveze iznose više od sedam i pol milijardi kuna na dan podnošenja prijedloga za otvaranje predmetnog postupka.

130 Pokroviteljska izjava može se izdati nakon otvaranja postupka izvanredne uprave radi davanja osiguranja za nova zaduženja tim postupkom obuhvaćenih društava, a sve radi ostvarenja ciljeva tog postupka. Hoće li, pritom, ispunjenje obveze iz tako dane izjave biti potrebno za redovito poslovanje društva od sistemskog rizika ovisi ponajprije o konkretnim okolnostima slučaja koje će procjenjivati izvanredni povjerenik. U slučaju krive procjene, prema odredbi čl. 12. st. 12. ZPIU-a izvanredni povjerenik odgovarat će za štetu kao stečajni upravitelj sukladno odredbi čl. 92. SZ-a. Pored toga, u konkretnom slučaju nije primjerena primjena pravila ZPIU-a o zaduženjima s prednošću namirenja jer se kod takvih zaduženja radi o potraživanjima koja se namiruju uz odgovarajuću primjenu pravila SZ-a o vjerovnicima stečajne mase s pravom prednosti prije drugih potraživanja. Ispunjenje obveze s naslova osiguranja, kao što je ispunjenje obveze pomaganja s naslova pokroviteljske izjave, gubi smisao kada se ono vrši tek kada postupak uđe u stadij namirenja stečajnih vjerovnika iz stečajne mase dužnika.

131 Tako vidi odredbu čl. 17. st. 5. i st. 6. ZFPPN-a.

132 Pritom valja upozoriti i na zabranu pokretanja ovršnog postupka i postupka osiguranja određenog odredbom čl. 41. ZPIU-a. Drugim riječima, vjerovnici postupkom obuhvaćenih društava ne mogu poduzimati pravne radnje usmjerene na ostvarenje namirenja potraživanja nastalih prije otvaranja postupka izvanredne uprave. Ispunjenje takvog potraživanja, međutim, može izvršiti izvanredni povjerenik sukladno odredbi čl. 40. ZPIU-a. 
o potraživanjima s naslova zaduženja s prednošću namirenja. ${ }^{133}$ To znači kako je ispunjenje obveze s naslova ranije izdane pokroviteljske izjave u postupku izvanredne uprave dvojako ograničeno, sadržajno i personalno. Takvo ispunjenje ograničeno je sadržajno time što se ono može učiniti samo ako je to nužno za smanjenje sistemskog rizika, nastavka poslovanja, očuvanja imovine i ako se radi o potraživanjima iz redovitog ili operativnog poslovanja. S druge strane, personalno ograničenje odnosi se na kvalifikaciju osobe vjerovnika takvog potraživanja. Ako je takva osoba financijska institucija (npr. neki od investicijskih fondova) ili kreditna institucija (npr. banka), ispunjenje obveze s naslova pokroviteljske izjave neće biti moguće ostvariti tijekom trajanja postupka izvanredne uprave. Za razliku od sadržajnog ograničenja, izneseno personalno ograničenje nije prikladno jer se njime diskriminiraju određene kategorije vjerovnika zbog čega valja de lege ferenda promisliti o njegovu ukidanju.

Postupkom izvanredne uprave obuhvaćena su i društva koja su povezana ili ovisna o društvu od sistemskog značaja. Takva se ovisnost određuje sukladno odredbi članka 475. ZTD-a, dok se povezanost oslanja na odredbu članka 473. ZTDa. ${ }^{134}$ Društvo od sistemskog značaja mora tada samostalno ili zajedno s povezanim i ovisnim društvima ispunjavati uvjete iz članka 4. stavka 2. ZPIU-a (uvjet prosječnog broja radnika i uvjet bilančne obveze). Ako takva povezana i ovisna društva imaju sjedište u inozemstvu, na njih nije moguća izravna primjena pravila ZPIU-a (npr. odredbe članka 13. stavka 4. ZPIU-a o ovlasti poduzimanja radnji u povezanim i ovisnim društvima), već samo primjena lex societatis. Izvanredni povjerenik, kao osoba koja samostalno i pojedinačno zastupa društvo koje je vladajuće ili povezano $\mathrm{s}$ inozemnim društvom, ima tada ovlaštenja zakonskog zastupnika tih društava. U okviru tog ovlaštenja izvanredni povjerenik postupa u granicama koje mu dopušta mjerodavno pravo za inozemno društvo (lex societatis). Na ispunjenje obveze pomaganja s naslova pokroviteljske izjave čiji je izdavatelj tuzemno povezano ili ovisno društvo obuhvaćeno postupkom izvanredne uprave, neovisno o tomu je li izjava dana prije ili nakon otvaranja postupka, primjenjuje se odredba članka 13. i 40. stavka 2. ZPIU-a. Prema toj odredbi, poslovanjem tih društava i dalje upravljaju osobe koje su bile ovlaštene voditi i zastupati takva društva prije otvaranja postupka izvanredne uprave (npr. članovi poslovodnog organa). Međutim, ovlaštene osobe ograničene su u vođenju poslova time što mogu poduzimati samo radnje koje su potrebne za redovito obavljanje poslovne djelatnosti. ${ }^{135}$ Poslovi i radnje koje prelaze taj opseg, kao i radnje

133 Tako vidi odredbu čl. 40. st. 4. ZPIU-a.

134 Tako je ovisno društvo ono društvo na koje vladajuće društvo može imati neposredno ili posredno prevladavajući utjecaj (čl. 475. st. 1. ZTD). Pritom se pretpostavlja kako je društvo koje se nalazi u većinskom sudjelovanju ovisno o društvu koje u njemu ima većinski udio (čl. 475. st. 2. ZTD), a smatra se kako neko društvo može imati prevladavajući utjecaj u drugome društvu, ako kao njegov član može izabrati i opozvati većinu članova poslovodnog organa društva (izvršnih direktora) ili članova nadzornog organa društva ili kada na temelju sporazuma s ostalim članovima ima kontrolu nad većinom glasačkih prava u tom društvu (čl. 475. st. 3. ZTD). S druge strane, prema odredbi čl. 5. st. 2. ZPIU-a povezano je društvo koje u drugome društvu ima većinski udio ili većinsko pravo odlučivanja (čl. 474. ZTD), zatim ovisno i vladajuće društvo (čl. 475. ZTD), društva koncerna (čl. 476. ZTD) i društvo s uzajamnim udjelima (čl. 477. ZTD).

135 Tako vidi odredbu čl. 13. st. 4. ZPIU-a. 
za koje je prema važećim propisima prava društava potrebna suglasnost nadzornog organa, mogu se poduzeti samo uz prethodnu suglasnost izvanrednog povjerenika. Izdavanje pokroviteljske izjave ili ispunjenje obveze pomaganja s naslova takve izjave, u pravilu se smatra poslom, odnosno radnjom koja prelazi okvir redovitog poslovanja, zbog čega je potrebno pribaviti prethodnu suglasnost izvanrednog povjerenika. Izostane li takva suglasnost, izdano osiguranje i pružena pomoć je valjana, ali će osobe ovlaštene na zastupanje tih društava odgovarati društvu za time nastalu štetu sukladno mjerodavnim pravilima o dužnoj pozornosti i odgovornosti članova poslovodnog organa društva. ${ }^{136}$ Ako je pokroviteljska izjava izdana prije otvaranja postupka izvanredne uprave, a tijekom postupka primatelj izjave traži ispunjenja ranije dospjele obveze pomaganja, valja primijeniti odredbu članka 40 . stavka 2. ZPIU-a. Ta odredba sadržajno odgovara odredbi članka 40. stavka 1. ZPIU-a pri čemu za poduzimanje radnji nije potrebna suglasnost vjerovničkog vijeća, već prethodna suglasnost izvanrednog povjerenika.

\section{ZAKLJUČAK}

Pokroviteljske izjave u poslovnom svijetu bitne su u situacijama kada se ugovorne strane, iako žele sklopiti neki posao, ne mogu o tomu sporazumjeti. Kako bi se premostilo nastalo nepovjerenje i nesigurnost, društvo majka jedne ugovorne strane, daje izjavu kojom nastoji pridonijeti jačanju povjerenja druge ugovorne strane o urednom namirenju njezina potraživanja. Slabe pokroviteljske izjave tako djeluju umirujuće na dvojbe i strahove primatelja izjave, dok kod izdavatelja stvaraju uvjerenje kako u slučaju neuspjeha željenog posla ne može biti tužen zbog neispunjenja svoje obveze (tzv. gentleman's agreement). Takve izjave pridonose sklapanju željenog posla jer premošćuju nastali jaz između suprotstavljenih očekivanja ugovornih strana i njihovih strahova o neuspjehu tog posla.

Daljnji razvoj pokroviteljskih izjava doveo je do nastanka čvrstih pokroviteljskih izjava koje se u pravnom spektru osiguranja nalaze između slabih pokroviteljskih izjava i garancije. Čvrstom pokroviteljskom izjavom pokrovitelj preuzima utuživu obvezu pomaganja treće osobe, ali mu istovremeno omogućuje i visoku razinu diskrecije u pogledu izbora i načina ispunjenja te obveze. Njegova obveza pomaganja usmjerena je na postizanje urednog ispunjenja osigurane obveze treće osobe (redovito

$136 \mathrm{U}$ tom pogledu valjalo bi primijeniti opće pravilo o ništetnosti ugovora s naslova odredbe čl. 322. st. 2. ZOO-a. Prema toj odredbi kada je sklapanje ugovora zabranjeno samo jednoj ugovornoj strani (društvu koje obuhvaćeno postupkom izvanredne uprave), ugovor je valjan, a strana koja je povrijedila zakonsku zabranu iz čl. 13. st. 4. ZPIU-a temeljem odredbe čl. 13. st. 5. ZPIU-a, odgovara za štetu zbog povrede dužne pozornosti prema odredbi čl. 252. ZTD-a. Također valja upozoriti kako se pravila sadržana u toj odredbi primjenjuju na društva kapitala zbog čega neka od rješenja nisu prikladna za društva osoba (npr. pravilo o oslobođenju od odgovornosti u slučaju odluke glavne skupštine, slučajevi naročite odgovornosti za štetu iz čl. 252. st. 3. ZTD-a i odricanje društva od prava na naknadu štete). Shodno tomu, na društva osoba valja primijeniti samo pravilo o dužnosti postupanja članova tih društava s pažnjom urednog i savjesnog gospodarstvenika, što je i uobičajeno pravilo za trgovačka društva osoba (npr. za javno trgovačko društvo vidi odredbu čl. 75. ZTD). 
društva kćeri pokrovitelja). Takvu izjavu posebno karakterizira njezina kvalifikacija kao atipičnog ugovora u korist trećega. To znači kako se obveza pomaganja ispunjava trećoj osobi kao korisniku pomoći, a ne primatelju izjave kao vjerovniku pokrovitelja. Takvo pomaganje neće nužno biti potrebno jer će treća osoba sama uredno ispuniti osiguranu obvezu, no kada to nije slučaj, pokrovitelj će uskočiti i pomoći trećoj osobi u ispunjenju te obveze. Čvrsta pokroviteljska izjava time predstavlja razuman kompromis kada pokrovitelj ne želi dati jače sredstvo osiguranja za takav posao (npr. jamstvo ili garanciju), a primatelj izjave uvjetuje sklapanje željenog posla pribavljanjem utuživog osiguranja.

Zbog njezine složene pravne strukture i naravi, čvrste pokroviteljske izjave stvaraju niz dvojbi u pravnom prometu. $U$ ispunjenju obveze pomaganja pokrovitelj je potpuno slobodan glede izbora sredstva i načina pružanja pomoći uz uvjet da takvo pomaganje treće osobe dovede do urednog ispunjenja osigurane obveze. Ne bude li pružena pomoć dostatna za uredno ispunjenje osigurane obveze pokrovitelj je dužan dodatno pomoći treću osobu radi njezina urednog ispunjenja osigurane obveze. Primatelj izjave pritom mora biti svjestan kako ga takvo osiguranje ne ovlašćuje da traži ispunjenje osigurane obveze izravno od pokrovitelja. Pravo izravnog ispunjenja osigurane obveze primatelju izjave pripada samo pokrovitelju koji će se tim pravom poslužiti kada mu je pomaganje treće osobe otegotnije od izravnog ispunjenja osigurane obveze vjerovniku. Preuzetu obvezu pomaganja treće osobe tada zamjenjuje obveza ispunjenja osigurane obveze pokrovitelju. Ne ispuni li treća osoba uredno osiguranu obvezu po njezinu dospijeću, pokrovitelj odgovara primatelju izjave za štetu koja mu nastane zbog toga. Takva utuživa odgovornost može pridonijeti sklapanju ugovora kod kojeg je potraživanje primatelja izjave osigurano predmetnom izjavom pokrovitelja.

U skladu s trendovima u razvijenim državama, za očekivati je kako će s vremenom doći i do učestalije primjene čvrstih pokroviteljskih izjava u domaćim trgovačkim ugovorima. U tom kontekstu domaći sudovi vjerojatno će se i učestalije susretati s predmetima vezanim za primjenu tog osiguranja. Sudovi, pritom, ne smiju zaboraviti kako je takva izjava ugovor autonomnog trgovačkog prava, detaljno razrađen u poredbenoj sudskoj praksi i pravnoj književnosti koja može i mora poslužiti sudovima u rješavanju takvih predmeta.

\section{LITERATURA}

Knjige i članci

Knjige

1. Barbić, J., Pravo društava, Knjiga druga, Društva kapitala, Svezak I., 6. izd., 2013., Zagreb

2. Barbić, J., Pravo društava, Knjiga druga, Društva kapitala, Svezak II., 6. izd., 2013., Zagreb

3. Baretić, M., Brežanski, J., Buljan, V., Ćurković, M., Hrvoj-Šipek, Z., Klarić, P., Momčinović, H., Nikšić, S., Odgovornost za štetu i osiguranje od odgovornosti za štetu, 2011., Zagreb

4. Blagojević, B. T., Krulj, V., Komentar Zakona o obligacionim odnosima I., 2. izd., 1983., Novi Sad 
5. Böhler, E., Bollenberger, R., Kellner, M., Laimer, S., Oppitz, M., Schwartze, A., Österreichisches Bankvertragsrecht, Band VIII: Kreidtsicherheiten, Teil I, 2. Aufl., 2012., Mörlenbach

6. Braun, E., Insolvenzordnung (InsO), Kommentar, 7. Aufl., 2017., München

7. Dauner-Lieb, B., Langen, W., BGB Schuldrecht, Band 2, 3. Aufl., 2016., Baden-Baden

8. Gorenc, V., Belanić, L., Momčinović, H., Perkušić, A., Pešutić, A., Slakoper, Z., Vukelić, M., Vukmir, B., Komentar Zakona o obveznim odnosima, 2. izd., 2014., Zagreb

9. Horn, J., Patronatserklärungen in common law und im deutschen Recht, 1999., Frankfurt am Main

10. Jakšić, T., Ugovor o jamstvu, doktorska disertacija, 2015., Zagreb

11. Kisser, J., Best Practice - Patronatserklärung, 2013., Wien

12. Kirchhof, H., Eidenmüller, H., Stürner, R., Münchener Kommentar zur Insolvenzordnung, Band 1, 3. Aufl., 2013., München

13. Koch, J., Patronatserklärung, 2005., Tübingen

14. La Corte, N., Die harte Patronatserklärung, Zugleich ein Plädoyer für eine geänderte Anlassrechtsprechung, 2006., Berlin

15. Larenz, K., Wolf, M., Allgemeiner Teil des Bürgerlichen Rechts, 9. Aufl., 2004., München

16. Mansel, H. J., von Staudingers Kommentar zum Bürgerlichen Gesetzbuch mit Einführungsgesetz und Nebengesetzen, Buch 2., Recht der Schuldverhältnisse, §§ 765778 (Bürgschaft), 14. Aufl., Neubearbeitung, 2013., Berlin

17. Markovinović, H., Ugovor o cesiji, doktorska disertacija, 2005., Zagreb

18. Perović, S., Stojanović, D., Komentar Zakona o obligacionim odnosima, 1. knjiga, 1980., Novi Sad

19. Schnellecke, C., Wirksamkeit und Inhaltskontrolle harter Patronatserklärungen, 2005., Frankfurt am Main

20. Schmidt, K., Insolvenzordnung, Band 27, 19. Aufl., 2016., München

21. Tödter, C., Bürgschaft und Patronatserklärung, 2013., Hamburg

\section{Članci}

1. Bilić, A., Ugovor u korist trećega, Zbornik Pravnog fakulteta u Zagrebu, 6 (2011)

2. Miladin, P., Bankarski računi pravnih i fizičkih osoba, Pravo u gospodarstvu, (2005), br. 4

3. Osrečak, J., Poredbenopravni prikaz načela savjesnosti i poštenja, Zagrebačka pravna revija, Svezak 3, br. 1 (2014)

4. Vukmir, B., Escrow račun (Escrow Account), Pravo i porezi, (2003), br. 3

5. Vukmir, B., Escrow račun kao instrument osiguranja plaćanja (Escrow Accounts), 2011., HGK - 16. forum poslovanja nekretninama

Pravni akti

Austrija, Republika

1. Allgemeines bürgerliches Gesetzbuch (ABGB)

\section{Hrvatska, Republika}

1. Stečajni Zakon (NN, br. 71/15)

2. Zakon o financijskom poslovanju i predstečajnoj nagodbi (NN, br. 108/12, 144/12, 81/13, $112 / 13,71 / 15$ i $78 / 15)$

3. Zakon o obveznim odnosima (NN, br. 35/05, 41/08, 125/11 i 78/15)

4. Zakon o postupku izvanredne uprave u trgovačkim društvima od sistemskog značaja za Republiku Hrvatsku (NN, br. 32/17) 
5. Zakon o trgovačkim društvima (NN, br. 111/93, 34/99, 121/99, 52/00, 118/03, 107/07, $146 / 08,137 / 09,125 / 11,111 / 12,68 / 13$ i 110/15)

Njemačka, Savezna Republika

1. Bürgerliches Gesetzbuch (BGB)

2. Insolvenzordnung ( $\mathrm{Ins} \mathrm{O})$ 


\author{
Tomislav Jakšić*
}

Summary

\title{
STRONG LETTERS OF COMFORT - LEGAL NATURE OF THE CONTRACT, CONTENT AND BREACH OF THE CONTRACTUAL OBLIGATION, INSOLVENCY AND EMERGENCY MANAGEMENT PROCEEDINGS
}

The issuer of the strong letter of comfort undertakes to provide assistance to a third person aimed at its orderly performance of secured obligation to the recipient of the letter. Such letters are normally issued as a result of a compromise in situations when the third party and the recipient are unable to reach an agreement on provision of other, more traditional, security instrument (e.g. suretyship or guarantee). Through issuance of such a letter a contractual relationship qualified as an atypical contract in favor of the third party is established. Third party (the debtor), although not a party to the contractual relationship between the issuer and the recipient of the letter, is regularly affiliated with the issuer of the letter. In such affiliation (e.g. through the group of companies or the undertaking contract) lies the interest of the recipient to undertake such a security for the third party. The paper elaborates on the legal nature of the issuer's obligation (especially in relation to the suretyship) whereat it touches upon the nature of such a unilateral contract as well. Thereupon the paper elaborates on the content and the measure of the issuer's obligation to provide assistance to the third person and then it gives a legal analysis of the possibility to exchange such an obligation with the performance of the secured obligation directly to the recipient of the letter. In addition, the effects of the breach of the issuer's obligation, its impossibility to perform its obligation and finally the insolvency and the emergency management proceedings are elaborated upon. In that regard rules on loan replacing the share capital are also analyzed.

Keywords: letter of comfort, security, insolvency, emergency management, affiliated companies.

* Tomislav Jakšić, Ph. D., Assistant Professor, Faculty of Law, University of Zagreb; tomislav. jaksic@pravo.hr. 
Zussamenfassung

\section{HARTE PATRONATSERKLÄRUNGEN - RECHTSNATUR DES VERTRAGS, GEGENSTAND UND VERLETZUNG DER PATRONATSPFLICHT, INSOLVENZVERFAHREN UND NOTFALLMANAGEMENTPROZESS}

Durch eine harte Patronatserklärung übernimmt der Patron die Pflicht, einem Dritten wegen Erfüllung seiner bei ihm bestehenden Verbindlichkeit gegenüber dem Empfänger der Patronatserklärung zu helfen. Solche Erklärungen sind meistens das Ergebnis des Kompromisses zwischen dem Patron und dem Empfänger der Patronatserklärung, wenn sich die beiden über kein traditionelles Sicherungsmittel (z.B. Bürgschaft oder Garantieerklärung) einigen können. Durch eine Patronatserklärung entsteht ein Vertragsverhältnis, welches regelmäßig als atypischer Vertrag zu Gunsten eines Dritten bezeichnet wird. Obwohl der Dritte (Schuldner) keine Vertragspartei des genannten Vertragsverhältnisses ist, ist er mit dem Patron verbunden (z.B. innerhalb eines Konzerns oder durch einen Unternehmensvertrag), weshalb der Patron ein Interesse an die Übernahme solcher Absicherung hat. Diese Arbeit bespricht die Rechtsnatur der Patronatspflicht (insbesondere im Vergleich zur Garantieerklärung) und bestimmt die Art eines solchen einseitigen Vertrags. Anschließend werden der Inhalt und Umfang der Patronatspflicht besprochen sowie auch die Möglichkeit, diese Pflicht zur Direktzahlung an den Empfänger der Patronatserklärung zu verwandeln. Eventuelle Verletzungen und Unmöglichkeit der Pflichterfüllung werden auch erörtert. Abschließend werden die Einwirkungen des Insolvenzverfahrens und des Notfallmanagements auf die Pflicht des Patrons besprochen. In dieser Hinsicht werden auch die Regeln des Darlehensvertrags, welche zur Ersetzung des Stammkapitals dienen, bearbeitet.

Schlüsselwörter: Patron, Sicherung, Insolvenz, Notfallmanagement, verbundene Unternehmen. 
Riassunto

\section{LETTERE D'INTENTI VINCOLANTI - NATURA GIURIDICA DEL CONTRATTO, OGGETTO E VIOLAZIONE DELL'OBBLIGO DEL DICHIARANTE, PROCEDIMENTO FALLIMENTARE E PROCEDIMENTO DI AMMINISTRAZIONE STRAORDINARIA}

Mediante la lettera d'intenti vincolante il dichiarante assume l'obbligo di aiutare un terzo soggetto nella regolare soddisfazione dell'obbligo garantito nei confronti del ricevente della dichiarazione. Tali dichiarazioni sovente sono il risultato del compromesso quando il dichiarante ed il ricevente la dichiarazione non riescono ad accordarsi circa l'utilizzo di uno strumento di garanzia più tradizionale (ad esempio fideiussione o garanzia). Mediante il rilascio della dichiarazione sorge un rapporto contrattuale che viene qualificato alla stregua di un contratto atipico a favore di terzo. Il terzo (debitore), benché non sia parte del rapporto contrattuale in oggetto, è regolarmente collegato al dichiarante (ad es. mediante la partecipazione in una consociata oppure mediante un contratto di rete); di qui l'interesse del dichiarante per la copertura. Il lavoro tratta della natura giuridica dell'obbligo del dichiarante (in particolare rispetto alla garanzia), toccando anche aspetti relativi alla determinazione della natura di tale contratto unilaterale. In seguito si disamina il contenuto e l'ampiezza dell'obbligo contratto dal dichiarante e, poi, anche la possibilità di sostituire l'obbligo di assistenza del terzo nell'adempimento dell'obbligazione con l'obbligo diretto di adempiere al creditore. Si disaminano anche le possibili violazioni e l'impossibilità dell'adempimento dell'obbligazione ed in conclusione gli effetti del procedimento fallimentare e del procedimento di amministrazione controllata sull'obbligazione contratta dal dichiarante. A tale riguardo si analizzano anche le regole sul contratto di prestito con il quale si sostituisce il capitale sociale.

Parole chiave: dichiarante, garanzia, fallimento, amministrazione controllata, società collegate. 
